OPEN ACCESS

Edited by:

Lasse Riemann

University of Copenhagen, Denmark

Reviewed by:

Hanna Maria Farnelid,

Linnaeus University, Sweden

Carolin Regina Löscher,

University of Southern Denmark

Odense, Denmark

*Correspondence:

Lauren F. Messer

laurenfrances.messer@student.

uts.edu.au

Specialty section:

This article was submitted to

Aquatic Microbiology,

a section of the journal

Frontiers in Microbiology

Received: 23 January 2017

Accepted: 15 May 2017

Published: 07 June 2017

Citation:

Messer LF, Brown MV, Furnas MJ,

Carney RL, McKinnon AD and

Seymour JR (2017) Diversity and Activity of Diazotrophs in Great

Barrier Reef Surface Waters.

Front. Microbiol. 8:967.

doi: 10.3389/fmicb.2017.00967

\section{Diversity and Activity of Diazotrophs in Great Barrier Reef Surface Waters}

\author{
Lauren F. Messer ${ }^{1,2 *}$, Mark V. Brown ${ }^{2}$, Miles J. Furnas ${ }^{3}$, Richard L. Carney ${ }^{1}$, \\ A. D. McKinnon ${ }^{3}$ and Justin R. Seymour ${ }^{1}$
}

\begin{abstract}
${ }^{1}$ Climate Change Cluster, School of Life Sciences, University of Technology Sydney, Sydney, NSW, Australia, ${ }^{2}$ School of Biotechnology and Biomolecular Sciences, University of New South Wales, Sydney, NSW, Australia, ${ }^{3}$ Australian Institute of Marine Science, Townsville, QLD, Australia
\end{abstract}

Discrepancies between bioavailable nitrogen $(\mathrm{N})$ concentrations and phytoplankton growth rates in the oligotrophic waters of the Great Barrier Reef (GBR) suggest that undetermined $\mathrm{N}$ sources must play a significant role in supporting primary productivity. One such source could be biological dinitrogen $\left(\mathrm{N}_{2}\right)$ fixation through the activity of "diazotrophic" bacterioplankton. Here, we investigated $\mathrm{N}_{2}$ fixation and diazotroph community composition over $10^{\circ} \mathrm{S}$ of latitude within GBR surface waters. Qualitative $\mathrm{N}_{2}$ fixation rates were found to be variable across the GBR but were relatively high

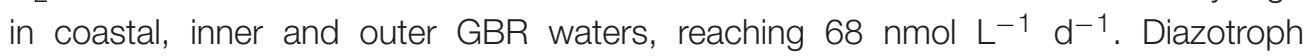
assemblages, identified by amplicon sequencing of the nifH gene, were dominated by the cyanobacterium Trichodesmium erythraeum, $\gamma$-proteobacteria from the Gamma A clade, and $\delta$-proteobacterial phylotypes related to sulfate-reducing genera. However, diazotroph communities exhibited significant spatial heterogeneity, correlated with shifts in dissolved inorganic nutrient concentrations. Specifically, heterotrophic diazotrophs generally increased in relative abundance with increasing concentrations of phosphate and $\mathrm{N}$, while Trichodesmium was proportionally more abundant when concentrations of these nutrients were low. This study provides the first in-depth characterization of diazotroph community composition and $\mathrm{N}_{2}$ fixation dynamics within the oligotrophic, $\mathrm{N}$-limited surface waters of the GBR. Our observations highlight the need to re-evaluate $\mathrm{N}$ cycling dynamics within oligotrophic coral reef systems, to include diverse $\mathrm{N}_{2}$ fixing assemblages as a potentially significant source of dissolved $\mathrm{N}$ within the water column.

Keywords: $\mathrm{N}_{2}$ fixation, Great Barrier Reef, diazotrophs, diversity, nifH amplicon sequencing

\section{INTRODUCTION}

The Great Barrier Reef (GBR), situated within the tropical waters of north-eastern Australia, is the largest continuous coral reef in the world and a region of high biological productivity (Furnas, 2003). Forming a natural barrier between coastal waters and the oligotrophic Coral Sea, the GBR is a biologically and biogeochemically dynamic system that is influenced by both localized hydrodynamic features (e.g., riverine discharge) (Devlin and Brodie, 2005; Waterhouse et al., 2012) and large-scale oceanographic processes (e.g., Coral Sea inflow and upwelling events) (Furnas and Mitchell, 1996; Brinkman et al., 2002; Choukroun et al., 2010). 
Concentrations and sources of particulate and dissolved nutrients in GBR waters vary across spatial gradients, such as between inshore and offshore regions (Furnas et al., 1995, 2011), but bioavailable forms of dissolved inorganic nutrients are generally low $(<0.05 \mu \mathrm{M})$ (Furnas et al., 2011). Excess concentrations of phosphate compared to dissolved inorganic nitrogen $(\mathrm{N}: \mathrm{P}, 1-3.5)$ indicate that nitrogen $(\mathrm{N})$ could be a limiting nutrient for phytoplankton growth (Furnas et al., 2011). Indeed, $\mathrm{NH}_{4}{ }^{+}$and $\mathrm{NO}_{3}{ }^{-}$stocks are typically turned over by phytoplankton within a matter of hours (Furnas et al., 2005). However, while low dissolved inorganic $\mathrm{N}$ to chlorophyll $a$ ratios indicate that phytoplankton growth cannot be supported for more than one doubling of biomass, the measured growth rates of phytoplankton populations across the reef are paradoxically high (Furnas et al., 2005). This discrepancy between bioavailable $\mathrm{N}$ and phytoplankton growth rate suggests that additional $\mathrm{N}$ sources play a significant role in supporting the phytoplankton assemblages within the pelagic waters of the GBR. One such $\mathrm{N}$ source could be provided by the activity of dinitrogen $\left(\mathrm{N}_{2}\right)$ fixing bacteria (diazotrophs).

Diazotroph activity is known to be an important source of bioavailable $\mathrm{N}$ within a number of discrete habitats in coral reefs systems. For example, $\mathrm{N}_{2}$ fixing lineages of proteobacteria and cyanobacteria are known constituents of the coral holobiont (Lema et al., 2012, 2014; Santos et al., 2014; Zhang et al., 2016), supplying fixed $\mathrm{N}$ to symbiotic Symbiodinium (Lesser et al., 2007; Ceh et al., 2013). $\mathrm{N}_{2}$ fixation has also been identified as an important process within coral reef sediments, contributing significantly toward $\mathrm{NH}_{4}{ }^{+}$pools within upper sediment layers (Capone et al., 1992; Alongi et al., 2006). In addition, particularly high rates of $\mathrm{N}_{2}$ fixation, attributable to the cyanobacterium Calothrix, have been reported within microbial mats on intertidal reef flats (Wiebe et al., 1975; Larkum et al., 1988).

In addition to symbiotic and benthic $\mathrm{N}_{2}$ fixation, pelagic diazotrophic cyanobacteria have also been shown to be abundant (Bell et al., 1999; Biegala and Raimbault, 2008) and active (Hewson et al., 2007) in the water column of coral reef lagoons. An earlier study of $\mathrm{N}_{2}$ fixation by the photoautotrophic cyanobacterium Trichodesmium in northern GBR waters suggested its potential importance in the provision of fixed $\mathrm{N}$ to primary production (Bell et al., 1999). However, within the Heron Island Lagoon on the GBR, Hewson et al. (2007) demonstrated for bacterioplankton possessing the nifH gene, which encodes a subunit of the dinitrogenase reductase enzyme, diazotrophs were most similar to microbial mat and sediment-associated cyanobacteria and proteobacteria. While Trichodesmium and other typically planktonic phylotypes were only detected within nifH transcripts, suggesting they may be active but rare members of the pelagic diazotrophic assemblage in this region (Hewson et al., 2007).

While the significance of $\mathrm{N}_{2}$ fixation for providing bioavailable $\mathrm{N}$ to coral reef ecosystems has been demonstrated by the quantitative incorporation of sedimentary and benthic reef flat $\mathrm{N}_{2}$ fixation rates into a GBR $\mathrm{N}$ budget, the contribution of pelagic $\mathrm{N}_{2}$ fixation to GBR $\mathrm{N}$ cycling is less well-understood (Furnas et al., 2011). The limited available information on the diversity, abundance and activity of diazotrophic bacteria within pelagic GBR environments has hindered efforts to develop a complete $\mathrm{N}$ budget for the GBR (Furnas et al., 2011). To address this gap, we measured $\mathrm{N}_{2}$ fixation rates and determined diazotroph community composition and abundance within GBR surface waters. Further, we investigated relationships between the observed spatial patterns in diazotroph assemblage structure and the prevailing biotic and abiotic environmental characteristics across the GBR.

\section{MATERIALS AND METHODS}

\section{Sample Collection}

Sampling was conducted during the Austral winter (6-18th July 2014), on a research voyage aboard the R/V Cape Ferguson (Australian Institute of Marine Science cruise 5913). The Austral winter coincides with the tropical dry season for the GBR, during which time GBR waters are generally characterized by reduced concentrations of dissolved inorganic $\mathrm{N}$, phosphorous, and chlorophyll $a$, and consequently lower rates of primary production compared to Austral summer, the tropical wet season (Furnas et al., 2005).

Seawater samples were collected using $10 \mathrm{~L}$ Niskin bottles mounted to a hydrographic wire from sub-surface waters $(5 \mathrm{~m})$, to ensure that only pelagic diazotrophs were sampled while avoiding benthic contamination. Temperature, salinity and chlorophyll fluorescence were determined using a Seabird SEB19+ Conductivity-Temperature-Depth recorder. Raw chlorophyll fluorescence readings from the CTD (Wetlabs Wetstar chlorophyll fluorometer) were empirically calibrated to in situ chlorophyll $a\left(\mu \mathrm{g} \mathrm{L}^{-1}\right)$ by building a calibration regression between fluorescence and discrete chlorophyll measurements from Niskin samples.

\section{Dissolved Inorganic Nutrient Analyses}

Samples for dissolved inorganic nutrient analyses, including $\mathrm{NO}_{\mathrm{x}}$ $\left(\mathrm{NO}_{3}{ }^{-}+\mathrm{NO}_{2}{ }^{-}\right), \mathrm{PO}_{4}{ }^{3-}$ and $\mathrm{SiO}_{4}{ }^{4-}(45 \mathrm{ml})$ were passed through a $0.45 \mu \mathrm{m}$ (Filtropur, Sarsedt) syringe filter, collected in $50 \mathrm{ml}$ Falcon tubes and stored at $-20^{\circ} \mathrm{C}$. Concentrations of $\mathrm{NO}_{\mathrm{x}}$, $\mathrm{PO}_{4}{ }^{3-}, \mathrm{SiO}_{4}{ }^{4-}$, were determined on a Flow Injection Analyzer (Lachat QuikChem 8000) at the Office for Environment and Heritage (Sydney, NSW, Australia), with a limit of detection of $0.01 \mu \mathrm{M}$. In addition, ammonium concentrations were analyzed at sea immediately after collection using the OPA fluorometric method (Holmes et al., 1999).

\section{Flow Cytometric Analyses}

Triplicate $1 \mathrm{ml}$ samples for microbial cell enumeration using flow cytometry (FCM) were fixed with glutaraldehyde (2\% final concentration), snap frozen and stored in liquid nitrogen onboard, prior to $-80^{\circ} \mathrm{C}$ storage post-voyage. Prior to FCM analysis, samples were quick-thawed and divided to enable the separate enumeration of bacteria $(200 \mu \mathrm{l})$ and autofluorescent picophytoplankton $(800 \mu \mathrm{l})$. Samples for bacterial enumeration were stained with SYBR Green I [1:10,000] (Invitrogen Molecular Probes, United States), while picophytoplankton samples were analyzed unstained. For both sample types, $1 \mu \mathrm{m}$ diameter 
fluorescent microspheres (Invitrogen Molecular Probes) were added as an internal reference (Marie et al., 1997; Gasol and del Giorgio, 2000). Samples were analyzed using a Becton Dickinson LSR II flow cytometer (BD Biosciences), with bacteria discriminated according to SYBR Green fluorescence and side-scatter, while picophytoplankton populations were discriminated according to orange (phycoerthyrin) fluorescence, red (chlorophyll $a$ ) fluorescence and side-scatter (Seymour et al., 2007). All data were analyzed using Cell-Quest Pro software (BD Biosciences).

\section{Dinitrogen Fixation Incubation}

For quantification of particulate carbon and $\mathrm{N}$ concentrations, and natural abundance stable isotope analyses $\left(\delta^{15} \mathrm{~N}, \mathrm{~T}_{0}\right.$ for $\mathrm{N}_{2}$ fixation incubations), between 1 and $4 \mathrm{~L}$ of seawater was filtered onto a pre-combusted glass fiber filter (GF/F, $0.7 \mu \mathrm{m}$ pore size, Whatman, United Kingdom), and stored at $-20^{\circ} \mathrm{C}$. Post-voyage, natural abundance filters were dried at $60^{\circ} \mathrm{C}$ for $48 \mathrm{~h}$ before being analyzed on an elemental analyzer (Thermo Finnigan MAT Conflo IV) coupled to an isotope ratio mass spectrometer (Thermo Finnigan Delta XP; limit of detection $=15 \mu \mathrm{g} \mathrm{N}$ per filter) (Research Corporation of the University of Hawaii).

At each station, triplicate $4 \mathrm{~L}$ polycarbonate, $\mathrm{HCl}$ clean Nalgene incubation bottles were filled via silicone tubing directly from Niskin bottles. Bottles were capped with septa without introducing headspace, then injected with $3 \mathrm{ml}{ }^{15} \mathrm{~N}_{2}$ gas (98 atom\%, Sigma-Aldrich, Australia) and inverted 100 times, leading to a theoretical enrichment of 7-8 atom\%, assuming complete dissolution of the ${ }^{15} \mathrm{~N}_{2}$ gas bubble (Montoya et al., 1996). Efforts were made to ensure that all injections occurred during the middle of the light period (approximately between 10 am and $2 \mathrm{pm}$ ). Bottles were incubated in deck-board incubators filled with continuously flowing surface sea water and shaded with Lee Filters 061 Mist Blue filter (Andover, United Kingdom) to replicate in situ light levels. After $\sim 24 \mathrm{~h}$, incubations were terminated by filtration onto pre-combusted GF/F $(0.7 \mu \mathrm{m}$ pore size, Whatman) and frozen at $-20^{\circ} \mathrm{C}$.

Post-voyage, enriched filters were dried separately from the natural abundance filters at $60^{\circ} \mathrm{C}$ for $48 \mathrm{~h}$, and isotopic composition along with total particulate $\mathrm{N}$ and carbon were determined using an elemental analyzer (Thermo Finnigan MAT Conflo IV) coupled to an isotope ratio mass spectrometer (Thermo Finnigan Delta XP; limit of detection $=15 \mu \mathrm{g} \mathrm{N}$ per filter) (Research Corporation of the University of Hawaii). Volumetric assimilation rates were calculated as previously described (Montoya et al., 1996), using a corrected atom\% enrichment value of $75 \%$ of the theoretical (Mohr et al., 2010), and are considered qualitative due to the known incomplete dissolution of the ${ }^{15} \mathrm{~N}_{2}$ gas bubble (Mohr et al., 2010; Großkopf et al., 2012).

\section{DNA Collection and Extraction}

Triplicate 2-4 L seawater samples were immediately filtered onto $0.2 \mu \mathrm{m}$ membrane filters (Durapore, Merck Millipore) and stored at $-20^{\circ} \mathrm{C}$ on-board (1-12 days), before being stored at $-80^{\circ} \mathrm{C}$ post-voyage. Microbial community DNA was extracted from preserved filters using the PowerWater DNA Extraction
Kit (MoBio Laboratories, Carlsbad, CA, United States) according to the manufacturer's instructions, with the exception of an additional 10 min heating step with solution PW1 to $60^{\circ} \mathrm{C}$ prior to $10 \mathrm{~min}$ of bead beating, to ensure complete cell lysis. DNA yield was quantified using a Broad Range DNA Qubit ${ }^{\mathrm{TM}}$ Assay (Invitrogen, Thermo Fisher Scientific, Scoresby, VIC, Australia) with a Qubit ${ }^{\mathrm{TM}} 2.0$ Fluorometer.

\section{Amplicon Sequencing Analysis}

The composition of the diazotrophic assemblage at each site was determined using a nested PCR protocol targeting a 327 base pair region of the nifH gene for biological replicates $(n=3)$ pooled in equal volumes. The two sets of degenerate primers included the nifH3 (5'-ATRTTRTTNGCNGCRTA- $\left.3^{\prime}\right)$ reverse and nifH4 (5' TTYTAYGGNAARGGNGG-3') forward primer pair, followed by the nifH1 (5'-TGYGAYCCNAARGCNGA-3') forward and the nifH2 reverse $\left(5^{\prime}\right.$-ADNGCCATCATYTCNCC- $\left.3^{\prime}\right)$ primer pair (Zehr and McReynolds, 1989; Zehr and Turner, 2001). PCR was performed using the following conditions: $95^{\circ} \mathrm{C}(2 \mathrm{~min})$ initial denaturation and 30 cycles of $95^{\circ} \mathrm{C}$ denaturation $(1 \mathrm{~min}), 48^{\circ} \mathrm{C}$ annealing $(1 \mathrm{~min})$ and $72^{\circ} \mathrm{C}$ extension $(1 \mathrm{~min})$, followed by a final extension at $72^{\circ} \mathrm{C}(10 \mathrm{~min})$. The nucleotide composition of nifH amplicons were identified using 454 pyrosequencing (Roche, FLX Titanium; Molecular Research LP) after an additional 10 PCR cycles with custom barcoded nifH1 and nifH2 primers under the same reaction conditions (Dowd et al., 2008; Messer et al., 2015a), with between 5110 and 10860 sequences retrieved per sample (3561-7939 high quality sequences; Supplementary Table 1). These sequences have been submitted to the Sequence Read Archive under accession numbers SRR3502520- SRR3502530.

The open source software "Quantitative Insights into Microbial Ecology” (QIIME) (Caporaso et al., 2010a) was used to analyze and process amplicon sequencing data. Raw nifH sequences were quality filtered, such that sequences with a quality score $<25$ and reads $<200$ base pairs in length were removed and subject to reference-based and de novo chimera removal using USEARCH61 with default parameters (Edgar, 2010). The reference database for chimera removal comprised unaligned nifH sequences exported from a custom nifH database (Zehr et al., 2003; Heller et al., 2014). Sequences were then clustered into operational taxonomic units (OTUs) at 97\% nucleotide sequence identity using UCLUST, whereby nifH sequences within $3 \%$ of the most abundant read were assigned as OTUs (Edgar, 2010). An OTU by sample table was generated and filtered to remove low abundance OTUs ( $<50$ sequences in total), then rarefied to the lowest number of sequences per sample (1394 sequences), resulting in a total of 92 OTUs. The FrameBot tool from the FunGene pipeline was used to identify any stop codons and correct frameshifts, and to simultaneously assign taxonomy based on amino acid identity (AAI) and alignment of the 92 OTUs to the Ribosomal Database Project nifH database (Fish et al., 2013). The PyNAST (Caporaso et al., 2010b) tool was then used with default parameters to BLAST and align representative nucleotide sequences from nifH OTUs to the closest nifH sequence in an aligned custom nifH database (exported from Arb) (Zehr et al., 2003; Heller et al., 2014). A maximum likelihood phylogenetic tree was generated from aligned OTUs (92 sequences) and 
publically available nifH sequences (121 nucleotide sequences) using the Tamura-Nai model in MEGA (v7.0) (Tamura and Nei, 1993; Kumar et al., 2016).

\section{Quantitative PCR (qPCR) Assays}

The two most abundant nifH clades observed in the amplicon sequencing analysis, representing Trichodesmium spp. and the Gamma A clade, were quantified directly using previously designed Taqman qPCR primers and probes (Table 1). These established qPCR assays were chosen because they targeted the dominant Trichodesmium and Gamma A OTUs from our amplicon pyrosequencing analyses. Specifically, 3 OTUs in our dataset (out of 92) shared 100\% identity between the forward primer, probe, and reverse primer designed to quantify Trichodesmium spp. by Church et al. (2005), including OTU5947, OTU3248, and OTU6010. While 6 OTUs (out of 92) shared $100 \%$ identity between the Gamma A forward primer, probe, and reverse primer, including OTU2275, OTU412, OTU4346, OTU481, OTU5337, OTU5802 of the Moisander et al. (2008, 2014) assay.

In order to generate qPCR standards, taxon specific PCR primers were used to amplify a fragment of the nifH gene target and the resultant product was cloned into a P-Gem T Easy Vector (Promega, Sydney, NSW, Australia) and transformed into competent TOPO Escherichia coli cells (Thermo Fisher Scientific, Scoresby, VIC, Australia). Following overnight growth at $37^{\circ} \mathrm{C}$ on LB agar plates containing ampicillin [50 mg/ml] and IPTG/Xgal, plasmids were extracted and purified from white colonies using the Plasmid Mini Kit (Bioline, Sydney, NSW, Australia). Confirmation of the correct nifH gene insert was completed using Sanger sequencing at the Australian Genome Research Facility. All nifH standards were serially diluted in sterile nucleic-acidfree $\mathrm{H}_{2} \mathrm{O}$ and a standard curve with concentrations ranging from $10^{2}$ to $10^{7}$ nifH copies was run alongside all samples, along with no template (negative) controls containing $5 \mu \mathrm{l}$ of nucleic-acid-free $\mathrm{H}_{2} \mathrm{O}$. To prevent inhibition of qPCR assays, template DNA was diluted $1 / 5$ using nucleic-acid-free $\mathrm{H}_{2} \mathrm{O}$. Following this, $5 \mu \mathrm{l}$ of the template dilution was used in the $20 \mu \mathrm{l}$ qPCR assays. Each qPCR reaction also included $200 \mathrm{nM}$ of each primer, $100 \mathrm{nM}$ probe, $2 \mathrm{x}$ TaqMan Master Mix II, $3 \mu \mathrm{l}$ of nucleic-acid-free $\mathrm{H}_{2} \mathrm{O}$. qPCR assays were run on triplicate biological replicates, including triplicate technical replicates for each sample and standard, using previously described reaction conditions (Table 1) (Church et al., 2005; Moisander et al., 2008, 2014) using a StepOnePlus ${ }^{\mathrm{TM}}$ Real-Time PCR machine (Applied
Biosystems, Thermo Fisher Scientific, Scoresby, VIC, Australia). Linear regression analyses of quantification cycle (Cq) versus $\log 10$ nifH gene copies were conducted using the StepOnePlus ${ }^{\text {TM }}$ software (v2.3), and demonstrated that our Trichodesmium assay had a mean $R^{2}$ of 0.999 and a reaction efficiency of $100.01 \%$ $(n=3)$, while the Gamma A assay had a mean $R^{2}$ of 0.996 and a reaction efficiency of $96.60 \%(n=3)$. The Cq limit for each assay was between 35 and 36 cycles (out of 40) equivalent to a detection of 5-6 nifH copies per reaction.

\section{Statistical Analyses}

Distance-based linear modeling (distLM) was used in order to identify relationships between environmental parameters and spatial heterogeneity (dissimilarity between sites) in diazotroph community composition (determined by amplicon sequencing) across the GBR. DistLM was performed on a square-root transformed Bray-Curtis dissimilarity matrix of 92 nifH OTUs, and standardized log transformed environmental parameters in the PRIMER + PERMANOVA software (v7, Clarke and Gorley, 2015). To identify relationships between the abundance of Trichodesmium spp. and the Gamma A clade (determined by qPCR), Pearson correlation coefficients were calculated between environmental parameters, and total bacterial and phytoplankton abundances (determined by flow cytometry) in Minitab (v17).

\section{RESULTS}

\section{Abiotic and Biotic Characteristics of GBR Surface Waters}

Samples were collected at 10 stations located between latitudes $12^{\circ} \mathrm{S}$ (northern GBR) and $23^{\circ} \mathrm{S}$ (southern GBR) and encompassed a variety of regions including coastal, central and outer GBR waters (Figure $\mathbf{1}$ and Supplementary Figure 1). Sea surface temperature (SST), salinity, and dissolved inorganic nutrient concentrations at the time of sampling were generally characteristic of the tropical oligotrophic conditions that prevail across most of the GBR (Figure 2 and Table 2). However, significant spatial heterogeneity in some of these environmental variables was observed across the 10 sampling sites. While salinity was relatively consistent, with a mean ( \pm standard deviation) of $35.2 \pm 0.2 \mathrm{PSU}$, SST varied with latitude between 21.2 and $26.3^{\circ} \mathrm{C}$, with a mean of $24.6 \pm 1.5^{\circ} \mathrm{C}$ (Figure 2A). Mean chlorophyll $a$ concentrations at the $5 \mathrm{~m}$ sampling depth were $0.34 \pm 0.15 \mu \mathrm{g} \mathrm{L}^{-1}$ and varied substantially from $0.08 \mu \mathrm{g} \mathrm{L}^{-1}$

TABLE 1 | Quantitative PCR primers, probes and reaction conditions for two nifH OTUs targeted during this study.

\begin{tabular}{lccr}
\hline Target & Forward primer & Reverse primer & TaqMan probe
\end{tabular}

achurch et al., 2005; b Moisander et al., 2008, 2014. All probes are 5'-FAM (dye) and TAMRA-3' (quencher). 


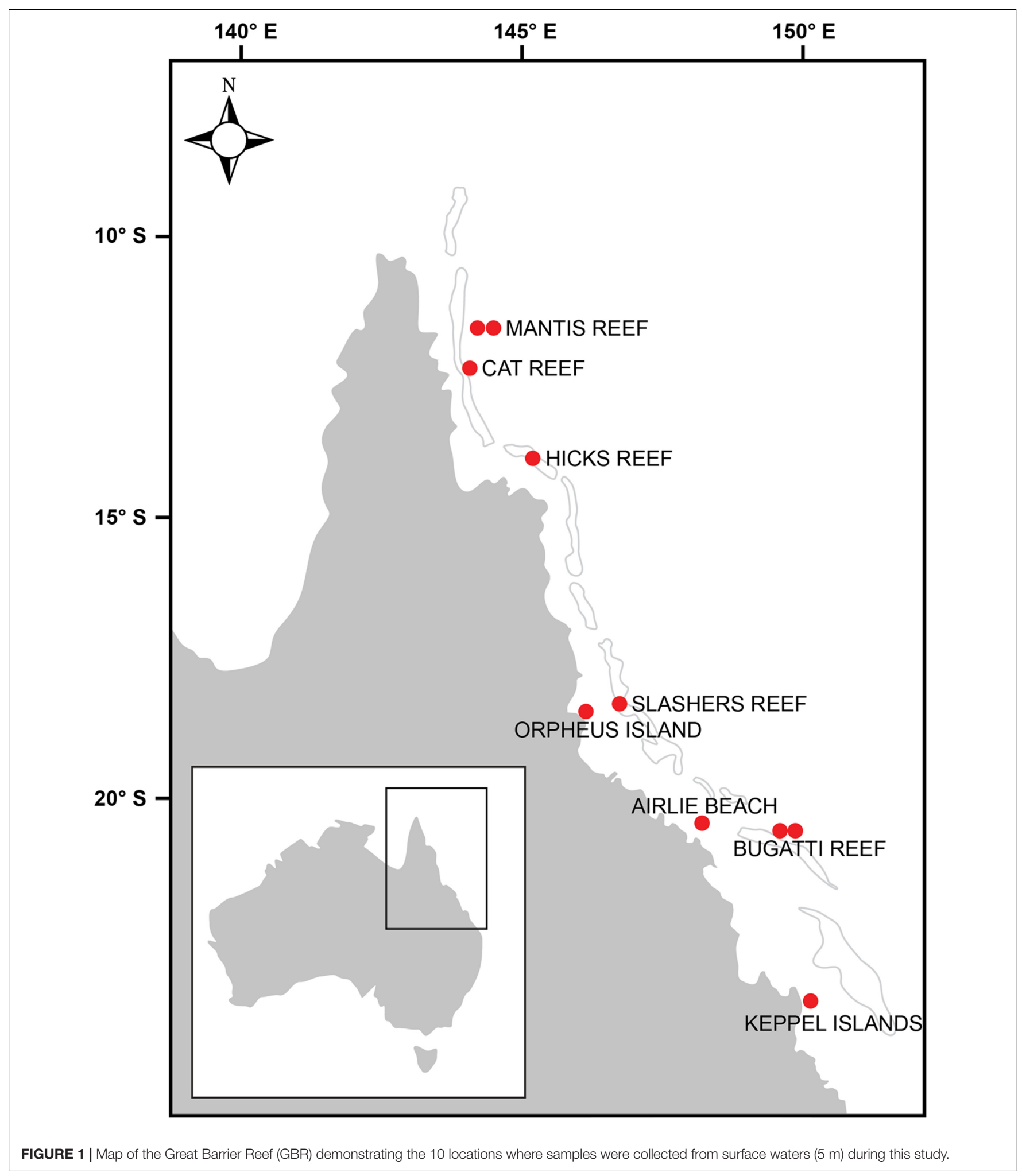

at the inner Mantis Reef site to $0.57 \mu \mathrm{g} \mathrm{L}^{-1}$ at Cat Reef (both northern GBR; Figure $\mathbf{1}$ and Table 2). Dissolved inorganic nutrients were generally low, with mean ammonia $\left(\mathrm{NH}_{3}\right)$, silicate $\left(\mathrm{SiO}_{4}{ }^{4-}\right)$, phosphate $\left(\mathrm{PO}_{4}{ }^{3-}\right)$, and oxides of nitrogen
$\left(\mathrm{NO}_{\mathrm{x}}=\mathrm{NO}_{3}^{-}+\mathrm{NO}_{2}^{-}\right)$concentrations of $0.06 \pm 0.06$, $0.85 \pm 0.47,0.02 \pm 0.01$, and $0.04 \pm 0.03 \mu \mathrm{M}$ respectively. $\mathrm{SiO}_{4}{ }^{4-}$ concentrations were the most variable, for example ranging from 0.33 to $1.88 \mu \mathrm{M}$ at the inner and outer Bugatti Reef sites (southern 
A
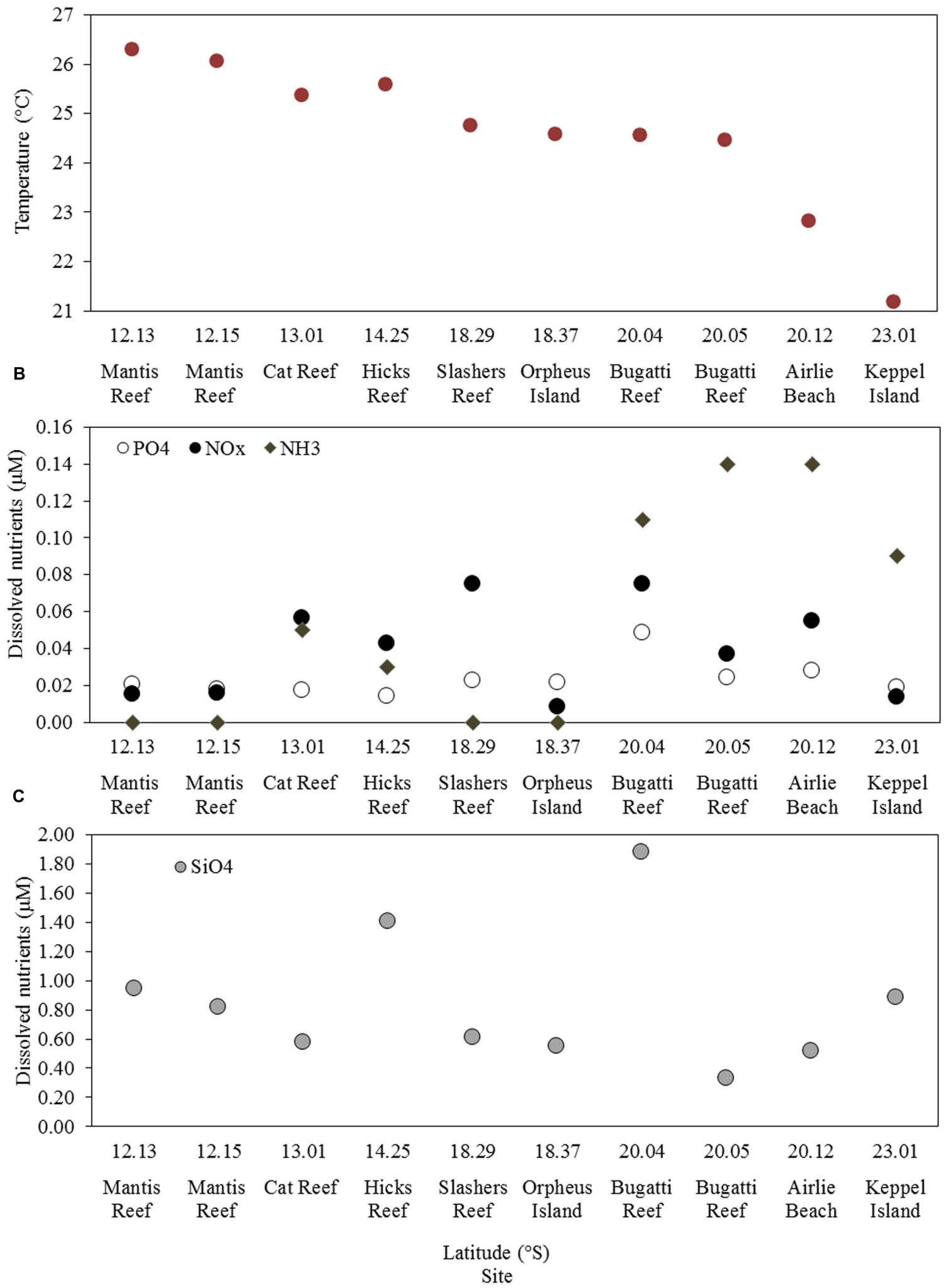

FIGURE 2 | Environmental characteristics of each study site including: (A) sea surface temperature (SST), (B) concentrations of $\mathrm{NH}_{3}, \mathrm{PO}_{4}$ and $\mathrm{NOx}$, (C) concentrations of $\mathrm{SiO}_{4}$. 
TABLE 2 | Locations of sampling stations shown in Figure 1 with environmental and contextual meta-data, including: salinity, chlorophyll a (Chla.), and cell counts determined by flow cytometry for total bacteria, Synechococcus (Syne.), Prochlorococcus (Proc.), and picoeukaryote (Pico.) populations.

\begin{tabular}{|c|c|c|c|c|c|c|c|c|c|c|}
\hline Station & Location & Lat. $\left({ }^{\circ} \mathrm{S}\right)$ & Long. ( $\left.{ }^{\circ} \mathrm{E}\right)$ & $\begin{array}{c}\text { Bottom } \\
\text { depth }(m)\end{array}$ & $\begin{array}{c}\text { Salinity } \\
\text { (PSU) }\end{array}$ & $\begin{array}{c}\text { Chla. } \\
\left(\mu \mathbf{g ~ L}^{-1}\right)\end{array}$ & $\begin{array}{c}\text { Total bacteria } \\
\left(\text { cells } \mathrm{ml}^{-1} \text { ) }\right.\end{array}$ & $\begin{array}{c}\text { Syne. } \\
\left(\text { cells } \mathrm{ml}^{-1}\right)\end{array}$ & $\begin{array}{c}\text { Proc. } \\
\text { (cells } \mathrm{ml}^{-1} \text { ) }\end{array}$ & $\begin{array}{c}\text { Pico. } \\
\text { (cells } \mathrm{ml}^{-1} \text { ) }\end{array}$ \\
\hline CSC82 & Mantis Reef & 12.13 & 143.52 & 270 & 35.09 & 0.31 & $9.4 \times 10^{5}$ & $9.8 \times 10^{4}$ & $1.1 \times 10^{5}$ & $5.0 \times 10^{3}$ \\
\hline CSC85 & Mantis Reef & 12.15 & 143.53 & 31 & 35.07 & 0.08 & $3.5 \times 10^{5}$ & $1.0 \times 10^{4}$ & $3.6 \times 10^{4}$ & $1.4 \times 10^{3}$ \\
\hline CSC88 & Cat Reef & 13.01 & 143.49 & 23 & 34.8 & 0.57 & nd & nd & nd & nd \\
\hline CSC89 & Hicks Reef & 14.25 & 145.26 & 300 & 35.04 & 0.21 & $5.5 \times 10^{5}$ & $6.2 \times 10^{4}$ & $9.1 \times 10^{4}$ & $6.6 \times 10^{3}$ \\
\hline CSC93 & Slashers Reef & 18.29 & 147.01 & 45 & 35.16 & 0.3 & $1.2 \times 10^{6}$ & $8.1 \times 10^{4}$ & $1.1 \times 10^{5}$ & $1.3 \times 10^{4}$ \\
\hline CSC81 & Orpheus Island & 18.37 & 146.28 & 24 & 35.37 & 0.43 & $1.2 \times 10^{6}$ & $2.1 \times 10^{5}$ & $3.8 \times 10^{4}$ & $6.5 \times 10^{3}$ \\
\hline CSC97 & Bugatti Reef & 20.04 & 150.17 & 65 & 35.2 & 0.31 & $8.0 \times 10^{5}$ & $5.6 \times 10^{4}$ & $4.8 \times 10^{4}$ & $5.4 \times 10^{3}$ \\
\hline CSC96 & Bugatti Reef & 20.05 & 150.18 & 18 & 35.21 & 0.43 & $8.1 \times 10^{5}$ & $7.3 \times 10^{4}$ & $6.7 \times 10^{4}$ & $4.4 \times 10^{3}$ \\
\hline CSC94 & Airlie Beach & 20.12 & 148.44 & 26 & 35.14 & 0.51 & $1.1 \times 10^{6}$ & $6.9 \times 10^{4}$ & $3.4 \times 10^{4}$ & $7.4 \times 10^{3}$ \\
\hline CSC98 & Keppel Island & 23.01 & 150.53 & 21 & 35.53 & 0.24 & $1.2 \times 10^{6}$ & $2.0 \times 10^{5}$ & $9.7 \times 10^{4}$ & $1.0 \times 10^{4}$ \\
\hline
\end{tabular}

GBR) respectively (Figure 2). In general, $\mathrm{NH}_{3}$ concentrations increased with latitude, ranging from below detection (displayed as $0.00 \mu \mathrm{M}$ ) at outer Mantis Reef (northern GBR) to $0.14 \mu \mathrm{M}$ in the coastal waters of Airlie Beach (southern GBR) (Figure 2).

We observed clear differences in the abundances of total bacteria, photosynthetic bacterioplankton and photosynthetic picoeukaryotes across the GBR (Table 2). For example, low abundances of all populations were observed at inner Mantis Reef in the northern GBR, while high abundances of all populations were observed in the coastal waters at Keppel Islands in the southern GBR (Table 2). In addition, higher abundances of bacteria $\left(1.2 \pm 0.04 \times 10^{6}\right.$ cells $\left.\mathrm{ml}^{-1}\right)$ and Synechococcus $\left(2.1 \pm 0.2 \times 10^{5}\right.$ cells $\left.\mathrm{ml}^{-1}\right)$ were observed at Orpheus Island (central GBR), and higher abundances of bacteria

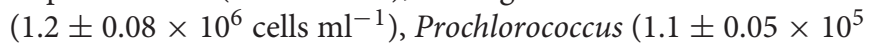
cells $\left.\mathrm{ml}^{-1}\right)$ and picoeukaryotes $\left(1.3 \pm 0.4 \times 10^{4}\right.$ cells $\left.\mathrm{ml}^{-1}\right)$ were observed at Slashers Reef (central GBR; Table 2).

\section{Rates of $\mathbf{N}_{\mathbf{2}}$ Fixation in GBR Waters}

Mean qualitative $\mathrm{N}_{2}$ fixation rates across the 10 sampling sites were $32 \pm 24 \mathrm{nmol} \mathrm{N} \mathrm{L}{ }^{-1} \mathrm{~d}^{-1}(n=30) . \mathrm{N}_{2}$ fixation rates were highly variable, ranging from a minimum of $3 \pm 0.8 \mathrm{nmol} \mathrm{N} \mathrm{L}{ }^{-1}$ $\mathrm{d}^{-1}$ at the inner Mantis Reef site, to a maximum of $68 \pm 11 \mathrm{nmol}$ $\mathrm{N} \mathrm{L}^{-1} \mathrm{~d}^{-1}$ at Cat Reef (both northern GBR). Comparatively high mean rates of $\mathrm{N}_{2}$ fixation $\left(\geq 30 \mathrm{nmol} \mathrm{N} \mathrm{L}{ }^{-1} \mathrm{~d}^{-1}\right.$ ) were observed at 6 out of the 10 sampling sites (Figure 3), while comparatively low rates $\left(\leq 9 \mathrm{nmol} \mathrm{N} \mathrm{L} \mathrm{N}^{-1} \mathrm{~d}^{-1}\right.$ ) were measured at three sites, including inner Mantis Reef in the north, and inner and outer Bugatti reef, southern GBR (Figure 3).

\section{Diazotroph Diversity and Abundance Across the GBR}

The nifH gene fragment was amplified from all sites within GBR waters, resulting in a total of 92 unique nifH OTUs at $97 \%$ nucleotide identity, and between 15 and 37 OTUs per sample, after quality filtering and removal of low abundance OTUs ( $<50$ total sequences; Supplementary Table 1$)$. The highest levels of diazotroph diversity (Shannon's diversity index, $\mathrm{H}^{\prime}=2.7$ ) occurred at the inner Mantis Reef site in the north and Slashers
Reef in the central GBR. While the lowest levels of diversity $\left(\mathrm{H}^{\prime}<1.3\right)$ were observed at Orpheus Island in the central GBR and at the outer Mantis Reef site in the northern GBR (Figure 4A).

Diazotrophic populations across the GBR included a range of OTUs that displayed sequence similarities to known Cluster IB photoautotrophic and photoheterotrophic cyanobacteria, as well as a number of Cluster IG and Cluster III proteobacterial diazotrophs (Figure 5 and Supplementary Figure 2). The most abundant OTU in the dataset was OTU5947, which shared 95\% AAI with the filamentous cyanobacterium Trichodesmium erythraeum, and clustered with representative and environmental Trichodesmium sequences (Figure 5A). OTU5947 represented $27 \%$ of total nifH sequences. This Trichodesmium OTU was present at each of the 10 sampling sites, from northern to southern waters, including coastal, inner reef and outer GBR locations, where maximum relative abundances of 44,19 , and $61 \%$ of nifH sequences occurred respectively (Figure 4B). Patterns in the Trichodesmium-specific qPCR analyses targeting OTU5947, OTU3248, and OTU6010, corresponded to those observed with the amplicon sequencing profiles, whereby the maximum abundance of Trichodesmium nifH copies $\mathrm{L}^{-1}$ occurred in the central GBR at Orpheus Island, at the outer Mantis Reef site in the north, and at Keppel Islands in the south, with mean abundances of $3.5 \times 10^{5}, 5.7 \times 10^{4}$, and $5.2 \times 10^{4}$ $\mathrm{L}^{-1}$, respectively (Figure 6).

Relative to Trichodesmium, other Cluster IB cyanobacterial nifH OTUs occurred less frequently in the dataset. For example, OTU4715, which shared 88\% AAI with the filamentous cyanobacterium Leptolyngbya spp., contributed only $2 \%$ to the total number of nifH sequences and was restricted to 2 out of 10 sites, where it comprised a maximum relative abundance of $15 \%$ of the diazotroph assemblage (Bugatti Reef; Figure 4B). Two other cyanobacterial OTUs, OTU888 and 1544, which shared 95 and 96\% AAI respectively with the unicellular cyanobacterium Candidatus Atelocyanobacterium thalassa (UCYN-A), also comprised only $\sim 2 \%$ of total nifH sequences. Interestingly, OTU888 clustered with representative sequences from the UCYN-A2 ecotype, while OTU1544 was more closely related to the UCYN-A1 ecotype (Figure 5A). These 


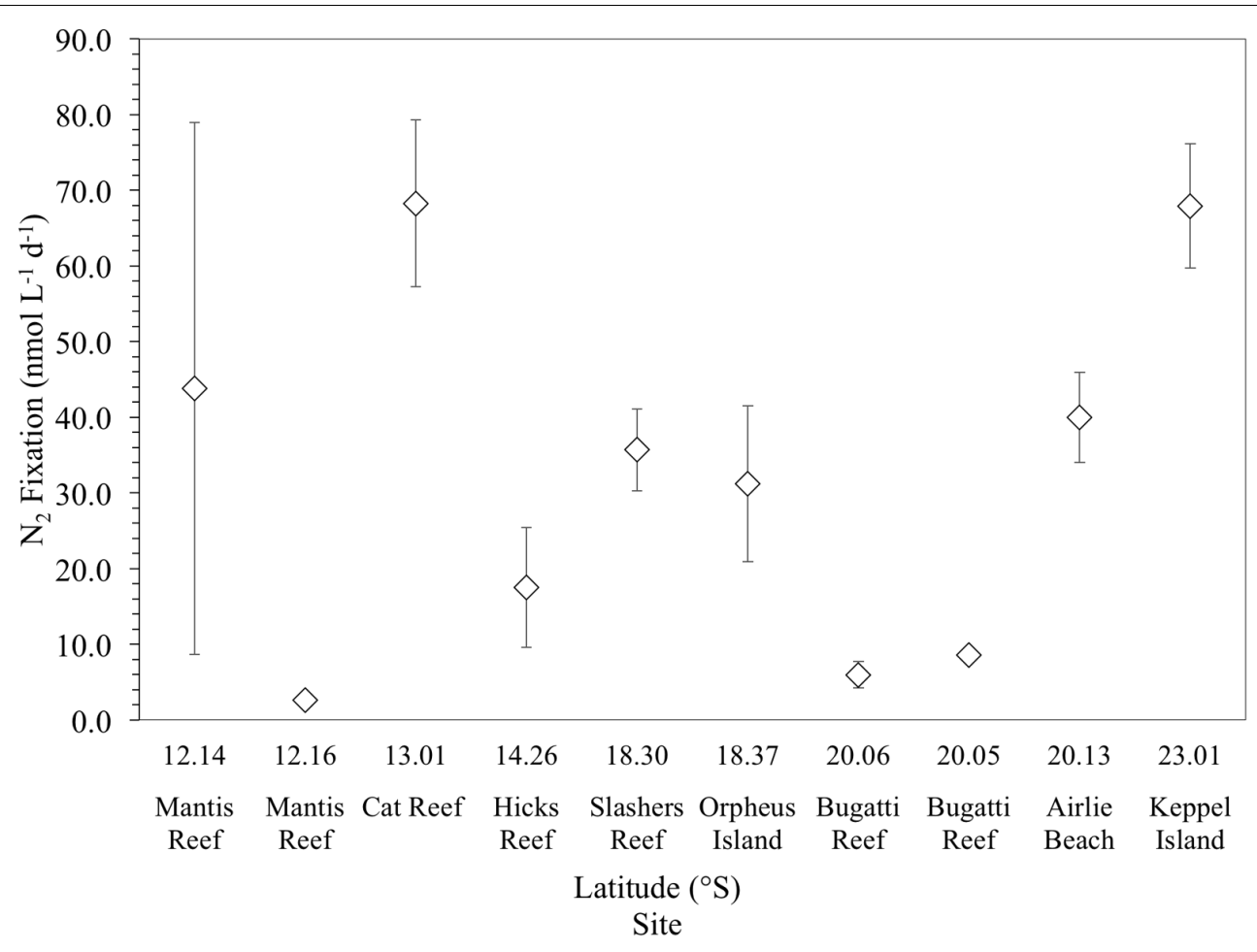

FIGURE 3 | Mean $\mathrm{N}_{2}$ fixation rates (nmol L ${ }^{-1} \mathrm{~d}^{-1}$ ) of triplicate incubations (corrected for the incomplete dissolution of ${ }^{15} \mathrm{~N}_{2}$ in seawater). Error bars represent the standard deviation about the mean.

two OTUs were present at two and four sites respectively, but did not make up more than $8 \%$ of the diazotroph assemblage when detected (e.g., Keppel Island, southern GBR; Figure 4B).

Outside of Cluster IB, significant numbers of nifH sequences associated with putative heterotrophic diazotrophs were detected, including representatives of the $\gamma$-proteobacteria from Cluster IG (Figure 5B and Supplementary Figure 2). The dominant heterotrophic nifH sequences were associated with the OTUs 5849 and 2275, which shared 91 and 88\% AAI with the $\gamma$-proteobacterium Pseudomonas stutzeri. Collectively, these $\gamma$-proteobacterial OTUs comprised $26 \%$ of total nifH sequences and, at their most abundant, made up 54 and $34 \%$ of the diazotroph assemblage at Orpheus Island (central GBR) and Hicks Reef (northern GBR) respectively (Figure 4B). One of these two OTUs, OTU2275 clustered with the Gamma A clade (Figure 5B), within the Marine 1 group (Langlois et al., 2015). qPCR analyses revealed that the Gamma A clade reached a maximum mean abundance of $5.9 \times 10^{2}$ nifH copies $\mathrm{L}^{-1}$ at the outer Mantis Reef site, in the northern GBR, but was not detectable at 5 out of 10 sites (Figure 5B). In addition, the Gamma A clade was typically found to be between 1 and 5 orders of magnitude less abundant than Trichodesmium, except at the Hicks Reef site in the north, where mean abundances of both taxa were $\sim 4.5 \times 10^{2}$ nifH copies $\mathrm{L}^{-1}$ (Figure 5).

Alongside the $\gamma$-proteobacterial nifH sequences, a number of sequences that were closely related to sulfate-reducing genera of the $\delta$-proteobacteria from Cluster III were also frequently detected, collectively comprising $17 \%$ of total nifH sequences
(Figures 4B, 5C). In particular, three OTUs (OTU891, 2257, and $5655)$ most closely related to members of Desulfovibrio spp. (90\% AAI) comprised $6 \%$ of total nifH sequences. OTUs 881 and 2257 were relatively widespread across the GBR, being present at eight and seven of the sampling sites respectively, comprising up to $13 \%$ of the diazotroph community at Hicks Reef, northern GBR (Figure 4B).

\section{Diazotroph Community Composition Correlates to $\mathrm{PO}_{4}$ and DIN Concentrations}

Distance-based linear modeling identified $\mathrm{PO}_{4}$ and dissolved inorganic $N$ (DIN) concentrations, as the measured environmental variables that were significant $(P<0.05)$ predictors of spatial heterogeneity in diazotroph community composition (Supplementary Table 2). Sites with higher $\mathrm{PO}_{4}$ and DIN concentrations, such as Hicks Reef in the north, outer and inner Bugatti Reef in the south, and the coastal waters of Airlie Beach, southern GBR (Figure 2 and Supplementary Figure 3), contained lower relative abundances of Trichodesmium nifH sequences, but higher relative abundances of the $\gamma$ and $\delta$-proteobacterial OTUs (Figure 4). However, no significant Pearson correlations were observed between the absolute abundances (derived by qPCR) of the Trichodesmium and Gamma A groups and any of the environmental parameters. In addition, despite evidence of variation in chlorophyll $a$ concentrations across the sampling sites (Table 2), indicative 


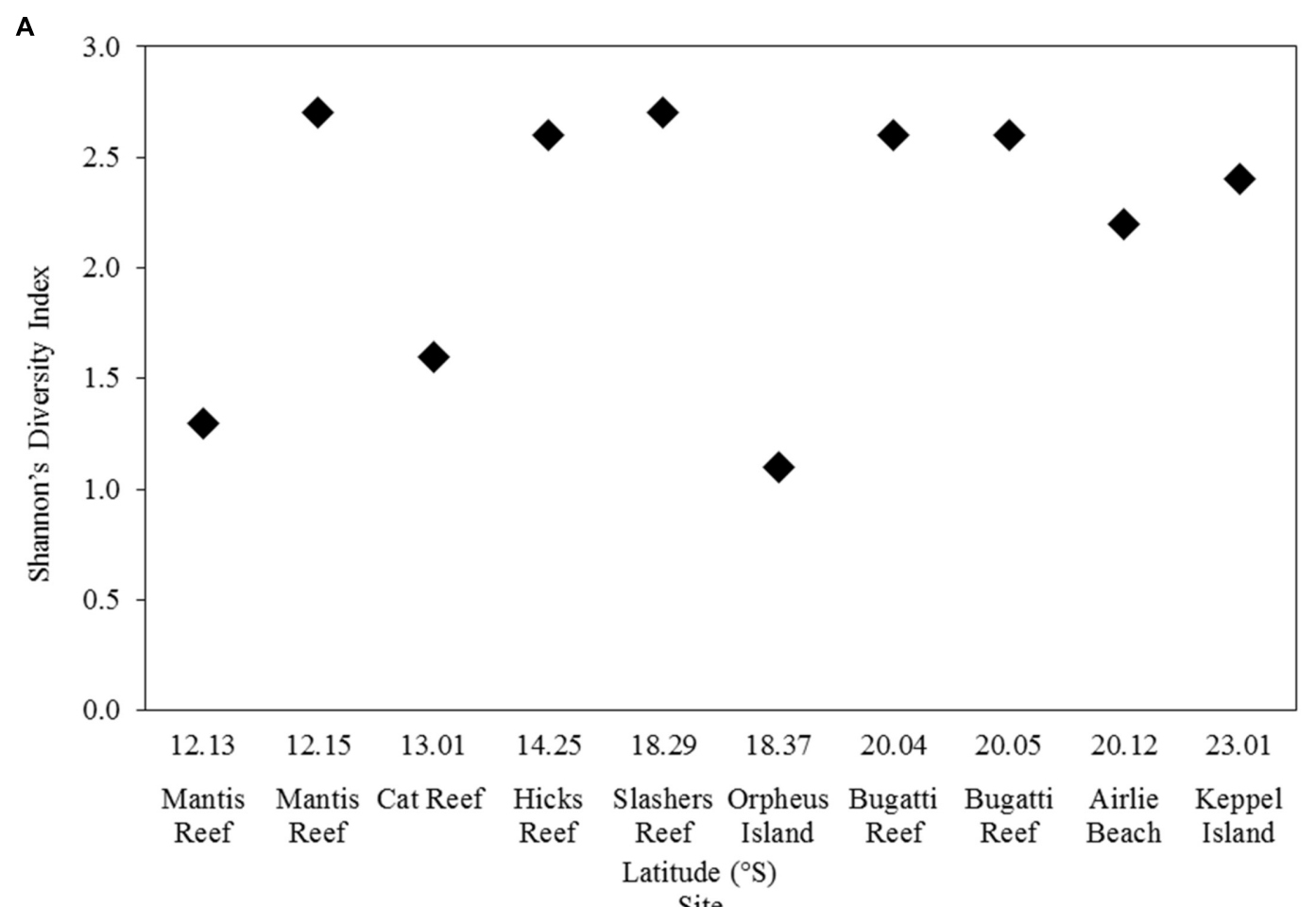

B

Site

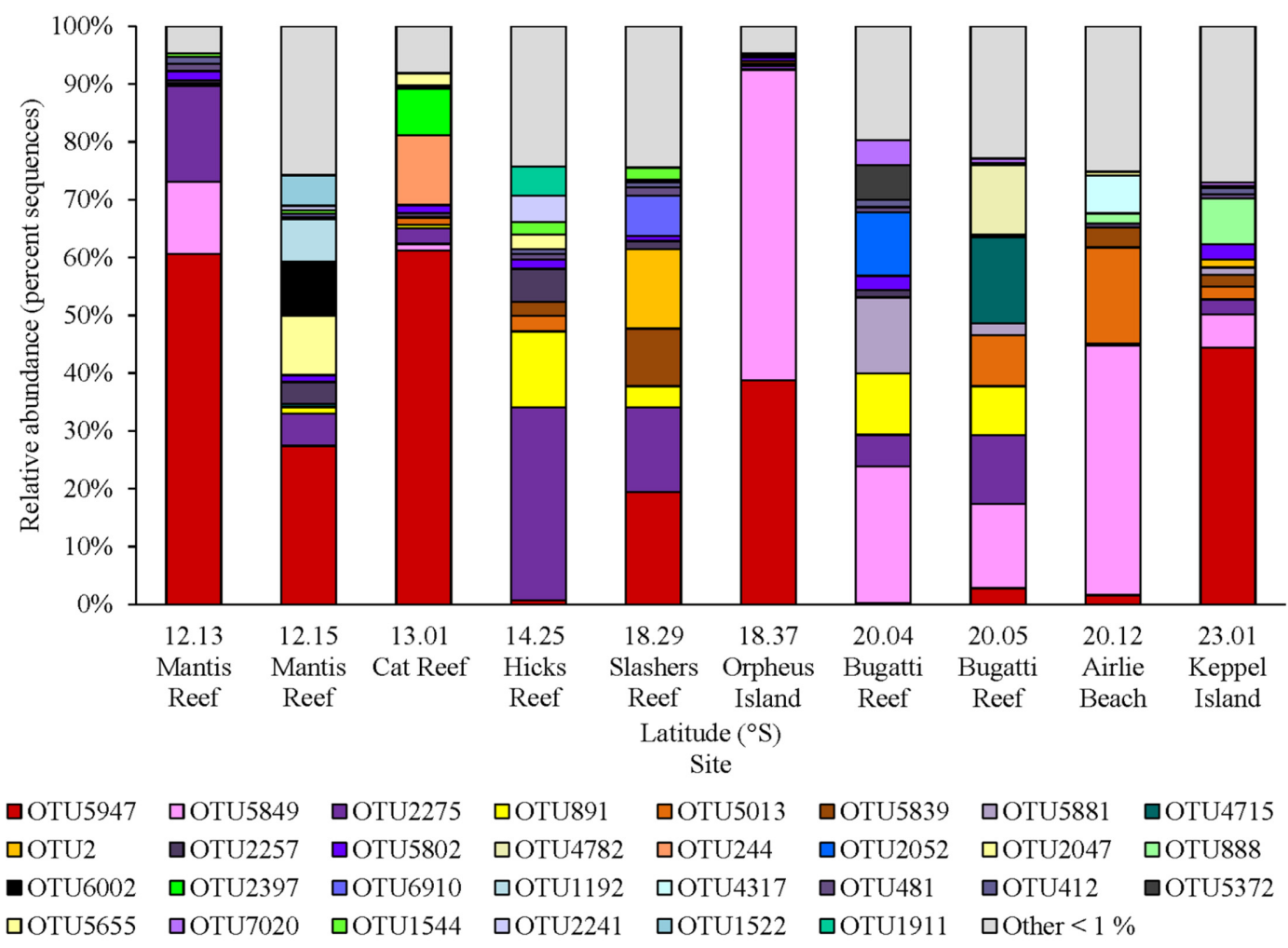

FIGURE 4 | Diazotroph assemblages within GBR surface waters, including (A) nifH diversity (Shannon's index) of rarefied sequence data and (B) relative abundance of nifH OTUs (\% of total sequences) clustered at $97 \%$ sequence similarity, with OTUs representing $<1 \%$ of total sequences grouped as "Other < $1 \%$." 


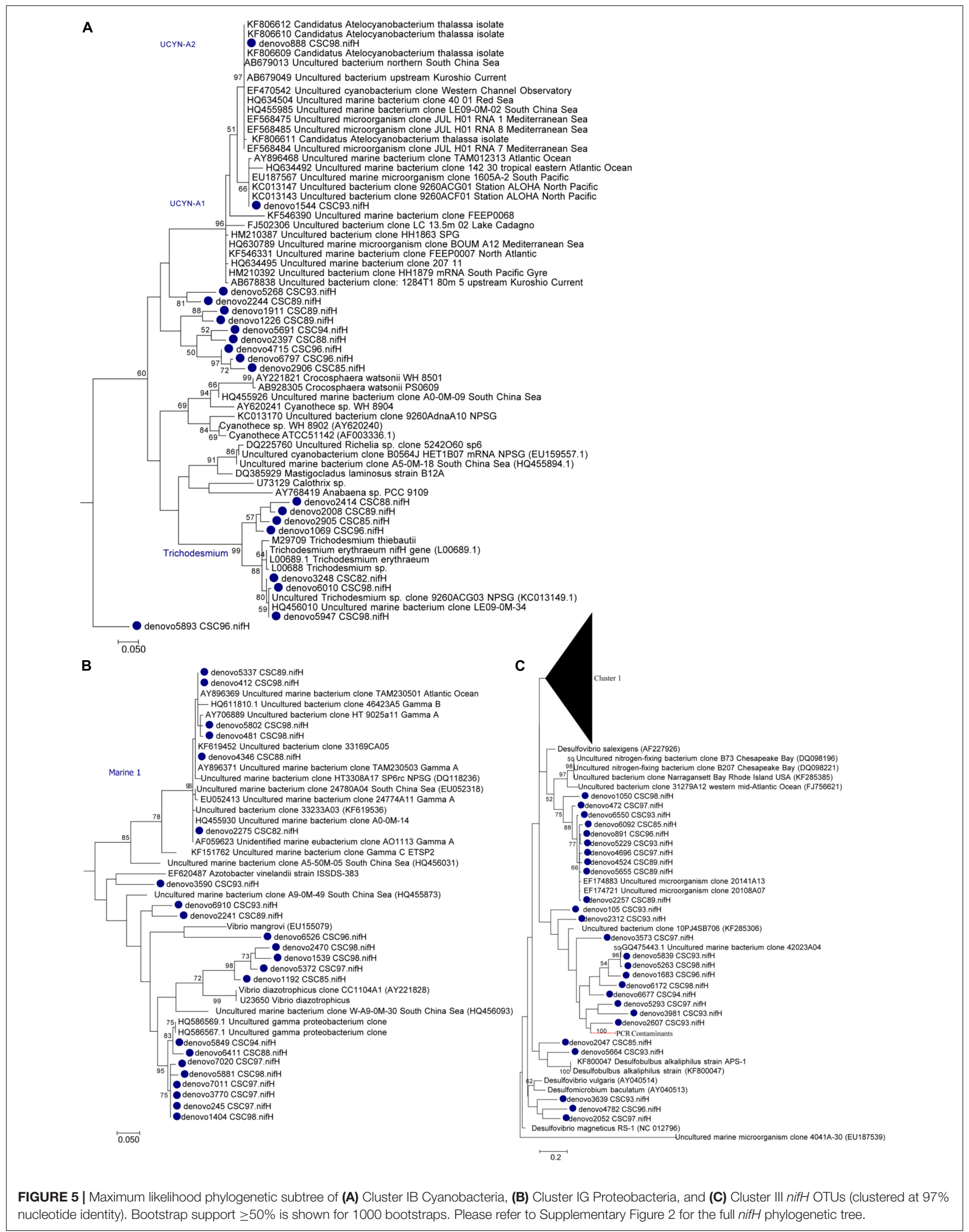



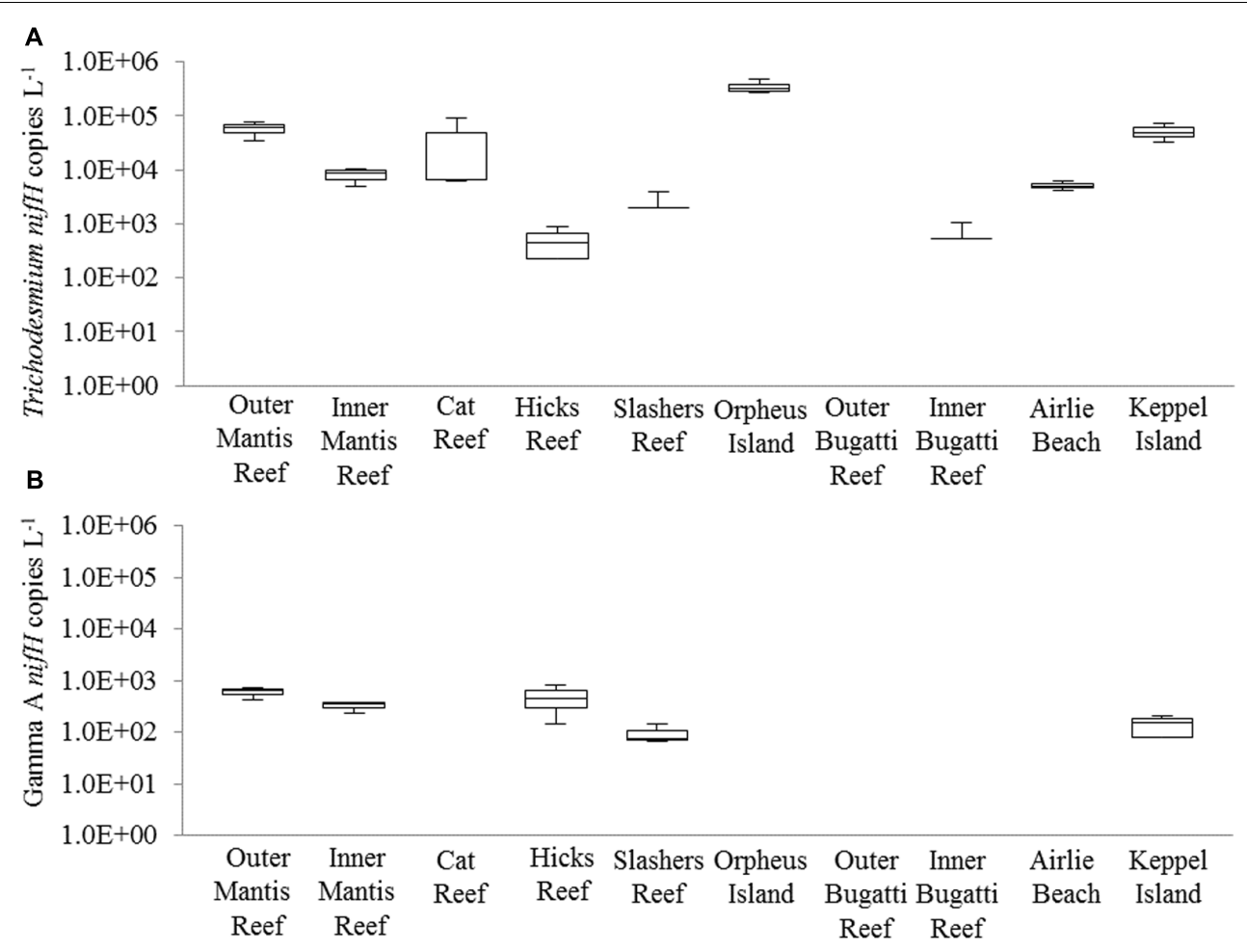

FIGURE 6 | Quantitative PCR (qPCR) abundances (nifH copies $\mathrm{L}^{-1}$ ) of (A) Trichodesmium and (B) the Gamma A clade across GBR sampling locations (from northern to southern waters). The box and whiskers represent the maximum value, 75th percentile, median value (50th percentile), 25 th percentile, and the minimum value for the triplicate biological replicates. Where no box is present, genes were detected but were below the limit of quantification and were therefore given values of "0." Please note the $y$-axis is shown on the log scale for clarity.

of changing phytoplankton biomass, no significant associations were observed between chlorophyll $a$ and diazotroph community composition.

\section{DISCUSSION}

The paradoxical nature of many coral reefs, whereby relatively high biological productivity occurs within marine waters where ambient concentrations of dissolved inorganic nutrients are low, has resulted in efforts to reconcile nutrient dynamics within coral reef systems (e.g., Furnas et al., 1995, 2005, 2011; Hearn et al., 2001; Falter et al., 2004; Schaffelke et al., 2012). Some early studies demonstrated that biological $\mathrm{N}_{2}$ fixation might play an important role in supplying bioavailable $\mathrm{N}$ within benthic reef habitats (Webb et al., 1975; Wiebe et al., 1975; Larkum et al., 1988), and more recently, diazotrophic bacteria have been shown to be an important constituent of the coral holobiont, supplying $\mathrm{N}$ requirements for symbiotic Symbiodinium (Lesser et al., 2004, 2007; Lema et al., 2012, 2014; Olson and Lesser, 2013; Zhang et al., 2016). However, within the pelagic environment of the GBR the role of biological $\mathrm{N}_{2}$ fixation is less well-understood (Furnas et al., 2011), despite evidence to suggest that large discrepancies exist between nutrient availability and phytoplankton growth (Furnas et al., 2005). Here, we found a diverse community of cyanobacterial and non-cyanobacterial diazotrophs inhabiting
GBR surface waters during Austral winter, and relatively high qualitative rates of $\mathrm{N}_{2}$ fixation within coastal, inner and outer reef habitats, indicating that diazotrophic bacterioplankton might act as a significant source of fixed $\mathrm{N}$ within the oligotrophic GBR.

Through our nifH amplicon sequencing analyses, we provide the first in-depth characterization of the potential for $\mathrm{N}_{2}$ fixation within bacterioplankton assemblages across the GBR. Using this approach, Cluster 1B cyanobacterial diazotrophs were identified as the dominant phylotype distributed throughout GBR surface waters, specifically OTUs closely related to Trichodesmium spp. showed high relative and absolute abundances. Seven OTUs sharing $>90 \%$ AAI to Trichodesmium erythraeum were detected in the amplicon sequencing dataset, three of which were targeted by the Trichodesmium spp. qPCR assay employed herein. Trichodesmium spp. are routinely observed in tropical, oligotrophic environments, including coral reef lagoons, where they can form large surface aggregations and contribute substantially to $\mathrm{N}_{2}$ fixation (Bell et al., 1999; Campbell et al., 2005; McKinna et al., 2011; Bonnet et al., 2015b; Turk-Kubo et al., 2015). Although surface aggregations were not observed during the present study, qPCR analyses indicated that the abundance of Trichodesmium spp. were at times high, reaching up to $3.5 \times 10^{5}$ nifH copies $\mathrm{L}^{-1}$, consistent with observations from the neighboring Coral and Solomon Seas during Austral winter conditions (Bonnet et al., 2015b). Trichodesmium has previously been recognized as an important feature of pelagic 
GBR microbial communities, through microscopic enumeration and satellite remote sensing (Bell et al., 1999; McKinna et al., 2011), and it is estimated that $\mathrm{N}_{2}$ fixation by Trichodesmium alone could contribute $\sim 0.7-3.0 \mathrm{t} \mathrm{N} \mathrm{km}^{-2}$ to GBR surface waters. At sites where qualitative $\mathrm{N}_{2}$ fixation rates of $\sim 68 \mathrm{nmol} \mathrm{L}^{-1} \mathrm{~d}^{-1}$ were observed, we found Trichodesmium to be abundant (3.4$5.2 \times 10^{4}$ nifH copies $\left.\mathrm{L}^{-1}\right)$. By virtue of both its abundance, diversity and activity, Trichodesmium therefore potentially plays a very important role in supporting the growth and production of non-diazotrophic assemblages across the GBR pelagic zone.

Beyond Trichodesmium, a number of other OTUs affiliated with Cluster 1B cyanobacterial diazotrophs were present in GBR surface waters. These included OTUs related to the filamentous genus Leptolyngbya, which has previously been found to actively fix $\mathrm{N}_{2}$ in benthic cyanobacterial mats (Woebken et al., 2014) including within coral reef systems (Charpy et al., 2010), and OTUs associated with the unicellular cyanobacterial symbiont UCYN-A, including ecotypes 1 and 2 which are widely distributed throughout the global ocean (Farnelid et al., 2016; Zehr et al., 2016). The majority of these Cluster 1B OTUs were present in relatively low abundances, contributing to $<15$ and $10 \%$ of nifH sequences at their maxima. The observed low relative abundance of UCYN-A1 and UCYN-A2 in GBR surface waters during Austral winter is consistent with our previous observations for the adjoining Coral Sea, whereby UCYN-A ecotypes effectively disappeared in Austral winter when compared to spring (Messer et al., 2015b). However, in the eastern Coral Sea, high UCYN-A abundances (determined by $\mathrm{qPCR}$ ) have been reported during Austral winter (Bonnet et al., 2015b), and UCYN-A has been reported to be the dominant diazotrophic phylotype within the Noumea Lagoon, New Caledonia (Turk-Kubo et al., 2015). While maximum abundances of UCYN-A appear to occur at more southern latitudes in the western South Pacific during Austral autumn (Moisander et al., 2010).

In addition to the cyanobacterial diazotrophs, our data provide the first estimates of the diversity and abundance of heterotrophic diazotrophs in GBR surface waters. Of particular importance were the Gamma A OTUs affiliated with Cluster 1G, which were the second most prevalent diazotrophic phylotype in our amplicon sequencing analyses. Specifically, OTUs clustering with the Gamma A group at times comprised $>50 \%$ of sequences at a given site, although the abundances of these organisms as determined by qPCR were generally low, with peaks of only $5.9 \times 10^{2}$ nifH copies $\mathrm{L}^{-1}$. This could reflect the possible preferential amplification of this phylotype by the PCR primers used in this study (Turk-Kubo et al., 2012), and highlights the importance of complementary qPCR analyses to verify amplicon sequencing based approaches. The abundance of Gamma A throughout GBR surface waters are in-line with previous studies utilizing Gamma A qPCR assays. For instance, Bonnet et al. (2015b) reported similar Gamma A abundances in the eastern Coral Sea and Solomon Sea, and Moisander et al. (2014) reported median Gamma A abundances of $8 \times 10^{2}$ nifH copies $\mathrm{L}^{-1}$ throughout the western South Pacific Ocean. Indeed, low abundances of Gamma A have been reported for much of the major ocean basins, indicating that they are a ubiquitous component of diazotrophic bacterioplankton in tropical, oligotrophic ecosystems (Langlois et al., 2015). Our data show the Gamma A clade to also be widespread throughout GBR surface waters, and it is particularly notable that members of this clade comprised a significant proportion of the diazotroph community at sites where relatively high qualitative rates of community $\mathrm{N}_{2}$ fixation were observed while Trichodesmium abundances were low.

Compared to the few other studies reporting water column $\mathrm{N}_{2}$ fixation rates in coral reef environments, the qualitative rates we observed in GBR waters were relatively high. For example, the highest rates observed here, between 31 and $68 \mathrm{nmol} \mathrm{L} \mathrm{L}^{-1} \mathrm{~d}^{-1}$, were greater than those observed in a New Caledonian coral lagoon ( $<10$ nmol L ${ }^{-1} \mathrm{~d}^{-1}$; Biegala and Raimbault, 2008), substantially greater than those reported for the eastern Coral Sea ( $\leq 2 \mathrm{nmol} \mathrm{L}{ }^{-1} \mathrm{~d}^{-1}$; Bonnet et al., 2015b), and in-line with those measured in the western Coral Sea, adjacent to the GBR (56 nmol L $\mathrm{L}^{-1} \mathrm{~d}^{-1}$; Messer et al., 2015b). Moreover, the rates observed in the present study are within the higher range of $\mathrm{N}_{2}$ fixation rates compiled within a global database of marine $\mathrm{N}_{2}$ fixation (Luo et al., 2012), indicating that $\mathrm{N}_{2}$ fixation within GBR waters indeed represents a significant source of $\mathrm{N}$ at the local scale, and a potentially significant region of $\mathrm{N}_{2}$ fixation activity at the global scale.

It must be noted, however, that the "bubble" method used to measure $\mathrm{N}_{2}$ fixation (Montoya et al., 1996) in this study, has previously been shown to underestimate $\mathrm{N}_{2}$ fixation by $50 \%$ or more, and will also depend on the composition of the underlying diazotroph community, as well as the time of sampling relative to the diurnal cycle of $\mathrm{N}_{2}$ fixation within specific clades, and the physical properties of the sampling site (e.g., temperature and salinity) which all influence the solubility of $\mathrm{N}_{2}$ gas in seawater (Mohr et al., 2010; Großkopf et al., 2012; Wilson et al., 2012; Benavides et al., 2013). Despite these caveats, the Montoya et al. (1996) method was applied in this study because it was decided that it was favorable to underestimate the significance of $\mathrm{N}_{2}$ fixation on the GBR, rather than potentially overestimate it by inadvertently introducing additional particulates, nutrients, or trace metals through pre-preparing ${ }^{15} \mathrm{~N}$ enriched natural or artificial seawater. Indeed, a recent study demonstrated that the preparation of ${ }^{15} \mathrm{~N}_{2}$ enriched seawater could result in the enrichment of trace metals by up to $0.1 \mathrm{nmol} \mathrm{L}^{-1}$, due to contact with standard laboratory ware used to prepare the solution (glass, rubber, and plastic) (Klawonn et al., 2015). Given that samples collected for each incubation experiment had distinct physical and chemical properties, such as variability in salinity and dissolved inorganic nutrient concentrations (Table 2), introducing enriched seawater that did not match the properties of the coastal, inner and outer GBR seawater sampled, could have influenced nutrient dynamics within our incubations. Therefore, our rate calculations were corrected according to Mohr et al. (2010) to account for the incomplete dissolution of ${ }^{15} \mathrm{~N}_{2}$ in seawater.

In addition, some commercially available ${ }^{15} \mathrm{~N}_{2}$ gas stocks have recently been found to be contaminated with ${ }^{15} \mathrm{NO}_{3},{ }^{15} \mathrm{NH}_{4}$, and ${ }^{15} \mathrm{~N}_{2} \mathrm{O}$ (Dabundo et al., 2014). Our study was performed prior to 
the publication of the Dabundo et al. (2014) study which reported the contamination of two batches of Sigma-Aldrich ${ }^{15} \mathrm{~N}_{2}$ gas stocks, and Sigma-Aldrich gas lot SZ1670V (2013 batch) was used in this study. We cannot explicitly rule out that there was not contamination in the batch of ${ }^{15} \mathrm{~N}_{2}$ that we used, therefore using the average concentration of ${ }^{15} \mathrm{NO}_{3},{ }^{15} \mathrm{NH}_{4}$, and ${ }^{15} \mathrm{~N}_{2} \mathrm{O}$ contamination in Sigma-Aldrich stocks reported by Dabundo et al. (2014) $\left(298,818\right.$, and $61 \mu \mathrm{mol} / \mathrm{mole}^{15} \mathrm{~N}$ respectively) we calculated that only an additional $3.2 \times 10^{-7}$ moles of ${ }^{15} \mathrm{~N}$ could have been added to our incubations during our trace additions $\left(2.7 \times 10^{-4}\right.$ moles) of ${ }^{15} \mathrm{~N}_{2}$ gas (Supplementary Table 3 ). Therefore, we found that any potential ${ }^{15} \mathrm{~N}$ contamination would have had a negligible effect on our measured rates of $\mathrm{N}_{2}$ fixation. Consequently, the rates of $\mathrm{N}_{2}$ fixation reported herein represent qualitative estimates of $\mathrm{N}_{2}$ fixation by a diverse population of diazotrophic bacterioplankton, and indicate that relatively high $\mathrm{N}_{2}$ fixation activity can occur in GBR waters.

Previous studies investigating diazotrophy within the water column of the GBR have either not measured $\mathrm{N}_{2}$ fixation rates (e.g., Hewson et al., 2007) or have measured $\mathrm{N}_{2}$ fixation rates by individual Trichodesmium trichomes using acetylene reduction (e.g., Bell et al., 1999). We propose that $\mathrm{N}_{2}$ fixation by the whole diazotroph community will significantly increase this estimate, and could theoretically support carbon fixation rates (assuming Redfield C:N ratios of phytoplankton) of between 0.2 and $4 \mu \mathrm{g}$ $\mathrm{C} \mathrm{L}^{-1} \mathrm{~d}^{-1}$. Although it is unlikely that all fixed $\mathrm{N}$ will be available to support $\mathrm{C}$ fixation, some autotrophic diazotrophs will directly contribute to primary production, while others may support primary production through the release of recently fixed $\mathrm{N}$ into the surrounding water column (Garcia et al., 2007; Lee Chen et al., 2011; Berthelot et al., 2015). For instance, the most abundant diazotroph observed in our study, the cyanobacterium Trichodesmium erythraeum, has been estimated to release between 50 and $90 \%$ of the $\mathrm{N}_{2}$ that it fixes into the surrounding environment (Glibert and Bronk, 1994; Mulholland et al., 2004), where it is potentially transferred to associated bacteria, non-diazotrophic filaments, or phytoplankton (Glibert and Bronk, 1994; Mulholland et al., 2004, 2006; Mulholland and Bernhardt, 2005).

While the fate of $\mathrm{N}$ fixed by heterotrophic diazotrophs remains unknown, dissolved $\mathrm{N}$ release from mixed, natural communities of diazotrophic bacterioplankton is in the range of $16-30 \%$ of gross whole community $\mathrm{N}_{2}$ fixation (Benavides et al., 2013; Bonnet et al., 2015a). Based on these numbers, we calculated potential dissolved $\mathrm{N}$ release, based on bulk qualitative $\mathrm{N}_{2}$ fixation rate measurements, in GBR waters to be between 0.4 and $20 \mathrm{nmol} \mathrm{L}{ }^{-1} \mathrm{~d}^{-1}$. Hence diazotroph-derived dissolved $\mathrm{N}$ could considerably increase the potential for $\mathrm{N}_{2}$ fixation to support primary production within GBR waters, where ambient concentrations of DIN are considered limiting.

In the present study, ambient concentrations of DIN $\left(\mathrm{NO}_{\mathrm{x}}+\right.$ $\mathrm{NH}_{3}$ ) across the GBR were relatively low at $<0.20 \mu \mathrm{M}$, but DIN concentration significantly contributed to the observed spatial heterogeneity in diazotroph community composition. Due to the reduced energy requirements associated with assimilating DIN $\left(\mathrm{NO}_{\mathrm{x}}+\mathrm{NH}_{3}\right)$ compared with fixing $\mathrm{N}_{2}$, biological $\mathrm{N}_{2}$ fixation is considered to be influenced by concentrations of DIN (Karl et al.,
2002; Knapp, 2012). In our study, where DIN concentrations were $\geq 0.11 \mu \mathrm{M}$ we observed relatively low rates of $\mathrm{N}_{2}$ fixation (between 2.6 and $5.9 \mathrm{nmol} \mathrm{L^{-1 }} \mathrm{d}^{-1}$ ) and more diverse diazotroph communities $\left(\mathrm{H}^{\prime}>2.5\right)$. Conversely, when DIN concentrations were $\leq 0.09 \mu \mathrm{M}$ we observed the highest rates of $\mathrm{N}_{2}$ fixation $\left(\sim 68 \mathrm{nmol} \mathrm{L}^{-1} \mathrm{~d}^{-1}\right)$, associated with less diverse diazotroph communities $\left(\mathrm{H}^{\prime}=\sim 1.5\right)$, typically dominated by Trichodesmium (at $30-50 \%$ of the diazotroph assemblage). In culture, cyanobacterial and proteobacterial diazotrophs have been shown to significantly decrease $\mathrm{N}_{2}$ fixation with increasing DIN concentrations (Knapp et al., 2012; Bentzon-Tilia et al., 2015), indicating a switch to DIN supported growth (Kustka et al., 2003; Masuda et al., 2013; Bentzon-Tilia et al., 2015), which may reduce the demand for dissolved iron (Kustka et al., 2003). However, in the environment $\mathrm{N}_{2}$ fixation is increasingly being found to occur outside of the classical ecological niche of low DIN waters (Fernandez et al., 2011; Knapp, 2012; Farnelid et al., 2013), and can even increase in response to simulated (mesocosm) and natural (mesoscale processes) co-additions of $\mathrm{N}$ with other nutrients (Dekaezemacker et al., 2013; Loscher et al., 2016). While the relationship between the availability of DIN and $\mathrm{N}_{2}$ fixation in the environment is more complex than perhaps previously thought, the patterns we observed suggest a significant role for DIN in structuring spatial heterogeneity in diazotroph community composition, which in turn could impact biological $\mathrm{N}_{2}$ fixation in GBR waters.

In addition to the influences of DIN, spatial heterogeneity in diazotrophic bacterioplankton was also significantly associated with the availability of the macro-nutrient phosphate. While ambient concentrations were generally low $(<0.05 \mu \mathrm{M})$, sites with higher phosphate concentrations $(0.024-$ $0.049 \mu \mathrm{M})$ contained diazotroph communities dominated by $\gamma$-proteobacterial OTUs, while lower phosphate concentrations (0.014-0.018 $\mu \mathrm{M})$ coincided with higher relative abundances of Trichodesmium. These observations may suggest differences in phosphate demand between the proteobacterial and cyanobacterial diazotrophs. Although previous phosphate enrichment experiments within GBR waters (Heron Island Lagoon) demonstrated no significant influence of phosphate on diazotroph abundance or nifH expression (Hewson et al., 2007), it is likely that a more complex relationship between phosphate concentration and $\mathrm{N}_{2}$ fixation exists within natural populations. Other sources of phosphorous, such as phosphonates (Dyhrman et al., 2006) and phosphites (Polyviou et al., 2015), may be utilized by diazotrophs in situ. Indeed, a recent ecosystem model that considers the availability of labile dissolved organic phosphorous (DOP) as a factor influencing diazotrophic activity, increased the estimated global $\mathrm{N}_{2}$ fixation budget by $30 \mathrm{Tg} \mathrm{N}$ $\mathrm{yr}^{-1}$ (Somes and Oschlies, 2015). Moreover, in situ mesocosm experiments in the tropical North Atlantic have provided direct evidence for the stimulation of $\mathrm{N}_{2}$ fixation after DOP addition, coinciding with a shift in diazotroph community composition (Meyer et al., 2016). Within the GBR, DOP estimates suggest concentrations similar to that of phosphate concentrations (Furnas et al., 2005), indicating that phosphate demand in GBR diazotroph communities could be met through labile DOP. Thus, the composition and abundance of GBR diazotroph assemblages 
are likely influenced by the availability of phosphate as well as other phosphorous sources, which, as our qualitative data indicates, may in turn significantly influence the activity of $\mathrm{N}_{2}$ fixation.

Overall, the findings of this study demonstrate that biological $\mathrm{N}_{2}$ fixation may be an important process within the pelagic realm of the GBR, where it has the potential to significantly support primary production. While we found that Trichodesmium dominates over spatially extensive areas of the GBR, heterotrophic $\mathrm{N}_{2}$-fixing bacteria may also be an important component of GBR diazotroph assemblages. Our findings indicate that diazotroph community composition is driven by the concentration of key dissolved inorganic nutrients, and in regions where DIN concentrations are low, high rates of $\mathrm{N}_{2}$ fixation can occur. These data highlight the need to re-evaluate $\mathrm{N}$ cycling dynamics within oligotrophic coral reef systems to include biological $\mathrm{N}_{2}$ fixation as a potentially significant source of dissolved $\mathrm{N}$ within the water column.

\section{AUTHOR CONTRIBUTIONS}

LM, MB, and JS designed the study. LM collected and processed samples, performed experiments and laboratory assays, and

\section{REFERENCES}

Alongi, D. M., Pfitzner, J., and Trott, L. A. (2006). Deposition and cycling of carbon and nitrogen in carbonate mud of the lagoons of Arlington and Sudbury Reefs, Great Barrier Reef. Coral Reefs 25, 123-143. doi: 10.1007/s00338-005-0069-2

Bell, P. R. F., Elmetri, I., and Uwins, P. (1999). Nitrogen fixation by Trichodesmium spp. in the central and northern great barrier reef lagoon: relative importance of the fixed-nitrogen load. Mar. Ecol. Prog. Ser. 186, 119-126. doi: 10.3354/ meps186119

Benavides, M., Bronk, D. A., Agawin, N. S. R., Perez-Hernandez, M. D., Hernandez-Guerra, A., and Aristegui, J. (2013). Longitudinal variability of sizefractionated N2 fixation and DON release rates along 24.5 degrees N in the subtropical North Atlantic. J. Geophys. Res. 118, 3406-3415. doi: 10.1002/jgrc. 20253

Bentzon-Tilia, M., Severin, I., and Hansen, L. H. (2015). Genomics and ecophysiology of heterotrophic nitrogen-fixing bacteria isolated from estuarine surface water. MBio 6, 1-11. doi: 10.1128/mBio.00929-15

Berthelot, H., Moutin, T., L'Helguen, S., Leblanc, K., Hélias, S., Grosso, O., et al. (2015). Dinitrogen fixation and dissolved organic nitrogen fueled primary production and particulate export during the VAHINE mesocosms experiment (New Caledonia lagoon). Biogeosci. Dis. 12, 4273-4313. doi: 10.5194/bgd-124273-2015

Biegala, I., and Raimbault, P. (2008). High abundance of diazotrophic picocyanobacteria $(<3 \mu \mathrm{m})$ in a southwest pacific coral lagoon. Aquat. Microb. Ecol. 51, 45-53. doi: 10.3354/ame01185

Bonnet, S., Berthelot, H., Turk-Kubo, K. A., Fawcett, S. E., Rahav, E., and LHelguen, S. (2015a). Dynamics of N2 fixation and fate of diazotrophderived nitrogen during the VAHINE mesocosm experiment. Biogeosci. Dis. 12, 19579-19626. doi: 10.5194/bgd-12-19579-2015

Bonnet, S., Rodier, M., Turk-kubo, K. A., Germineaud, C., Menkes, C., Ganachaud, A., et al. (2015b). Contrasted geographic distribution of N2 fixation rates and nifH phylotypes in the Coral and Solomon Seas (southwest Pacific) during austral winter conditions. Glob. Biogeochem. Cycles 29, 1874-1892. doi: 10.1002/2015GB005117

Brinkman, R., Wolanski, E., Deleersnijder, E., McAllister, F., and Skirving, W. (2002). Oceanic inflow from the coral sea into the great barrier reef. Estuar. Coast. Shelf Sci. 54, 655-668. doi: 10.1006/ecss.2001.0850 analyzed and interpreted the data. AM and MF provided field support, CTD data, and collected samples. RC assisted with flow cytometry and dissolved nutrient analyses. LM, MB, and JS wrote the manuscript, with input from all authors. All authors approved the manuscript.

\section{ACKNOWLEDGMENTS}

We would like to thank the captain, crew and scientists on-board RV Cape Ferguson for their support during sample collection. We are extremely grateful for ship time provided by the Australian Institute of Marine Science. This research was supported by the Australian Research Council Discovery Project grant scheme (DP120102764 awarded to JS and MB, and DP150102326 to MB). JS was supported by ARC Future Fellowship FT130100218. MB was supported by ARC QEII Fellowship DP0988002.

\section{SUPPLEMENTARY MATERIAL}

The Supplementary Material for this article can be found online at: http://journal.frontiersin.org/article/10.3389/fmicb. 2017.00967/full\#supplementary-material

Campbell, L., Carpenter, E. J., Montoya, J. P., Kustka, A., and Capone, D. G. (2005). Picoplankton community structure within and outside a Trichodesmium bloom in the southwestern Pacfic Ocean. Vie et Milieu 55, 185-195.

Capone, D. G., Dunham, S. E., Horrigan, S. G., and Duguay, L. E. (1992). Microbial nitrogen transformations in unconsolidated coral reef sediments. Mar. Ecol. Prog. Ser. 80, 75-88. doi: 10.3354/meps080075

Caporaso, J., Bittinger, K., Bushman, F. D., Desantis, T. Z., Andersen, G. L., and Knight, R. (2010a). PyNAST: a flexible tool for aligning sequences to a template alignment. Bioinformatics 26, 266-267. doi: 10.1093/bioinformatics/btp636

Caporaso, J., Kuczynski, J., Stombaugh, J., Bittinger, K., Bushman, F., Costello, E. K., et al. (2010b). QIIME allows analysis of high-throughput community sequencing data. Nat. Methods 7, 335-336. doi: 10.1038/nmeth0510-335

Ceh, J., Kilburn, M. R., Cliff, J. B., Raina, J. B., van Keulen, M., and Bourne, D. G. (2013). Nutrient cycling in early coral life stages: pocillopora damicornis larvae provide their algal symbiont (Symbiodinium ) with nitrogen acquired from bacterial associates. Ecol. Evol. 3, 2393-2400. doi: 10.1002/ece3.642

Charpy, L., Palinska, K. A., Casareto, B., Langlade, M. J., Suzuki, Y., Abed, R. M. M., et al. (2010). Dinitrogen-fixing cyanobacteria in microbial mats of two shallow coral reef ecosystems. Microb. Ecol. 59, 174-186. doi: 10.1007/s00248-0099576-y

Choukroun, S., Ridd, P. V., Brinkman, R., and McKinna, L. I. W. (2010). On the surface circulation in the western coral sea and residence times in the great barrier reef. J. Geophys. Res. Ocean. 115, C06013. doi: 10.1029/2009JC005761

Church, M. J., Jenkins, B. D., Karl, D. M., and Zehr, J. P. (2005). Vertical distributions of nitrogen-fixing phylotypes at Station ALOHA in the oligotrophic North Pacific Ocean. Aquat. Microb. Ecol. 38, 3-14. doi: 10.3354/ ame038003

Clarke, K. R., and Gorley, R. N. (2015). PRIMER v7: User Manual/Tutorial. Plymouth: PRIMER-E Ltd.

Dabundo, R., Lehmann, M. F., Treibergs, L., Tobias, C. R., Altabet, M. A., Moisander, P. H., et al. (2014). The contamination of commercial 15N2 Gas Stocks with $15 \mathrm{~N}$-labeled nitrate and ammonium and consequences for nitrogen fixation measurements. PLOS ONE 9:e110335. doi: 10.1371/journal. pone.0110335

Dekaezemacker, J., Bonnet, S., Grosso, O., Moutin, T., Bressac, M., and Capone, D. G. (2013). Evidence of active dinitrogen fixation in surface waters of the eastern tropical South Pacific during El Niño and la Niña events and evaluation 
of its potential nutrient controls. Glob. Biogeochem. Cycles 27, 768-779. doi: $10.1002 / g b c .20063$

Devlin, M. J., and Brodie, J. (2005). Terrestrial discharge into the great barrier reef lagoon: nutrient behavior in coastal waters. Mar. Pollut. Bull. 51, 9-22. doi: 10.1016/j.marpolbul.2004.10.037

Dowd, S. E., Callaway, T. R., Wolcott, R. D., Sun, Y., McKeehan, T., Hagevoort, R. G., et al. (2008). Evaluation of the bacterial diversity in the feces of cattle using $16 \mathrm{~S}$ rDNA bacterial tag-encoded FLX amplicon pyrosequencing (bTEFAP). BMC Microbiol. 8:125. doi: 10.1186/1471-2180-8-125

Dyhrman, S. T., Chappell, P. D., Haley, S. T., Moffett, J. W., Orchard, E. D., Waterbury, J. B., et al. (2006). Phosphonate utilization by the globally important marine diazotroph Trichodesmium. Nature 439, 68-71. doi: 10.1038/ nature 04203

Edgar, R. C. (2010). Search and clustering orders of magnitude faster than BLAST. Bioinformatics 26, 2460-2461. doi: 10.1093/bioinformatics/btq461

Falter, J. L., Atkinson, M. J., and Merrifield, M. A. (2004). Mass-transfer limitation of nutrient uptake by a wave-dominated reef flat community. Limnol. Oceanogr. 49, 1820-1831. doi: 10.4319/lo.2004.49.5.1820

Farnelid, H., Bentzon-Tilia, M., Andersson, A. F., Bertilsson, S., Jost, G., Labrenz, M., et al. (2013). Active nitrogen-fixing heterotrophic bacteria at and below the chemocline of the central Baltic Sea. ISME J. 7, 1413-1423. doi: $10.1038 /$ ismej.2013.26

Farnelid, H., Turk-Kubo, K., Del Carmen Munoz-Marin, M., and Zehr, J. P. (2016). New insights into the ecology of the globally significant uncultured nitrogenfixing symbiont UCYN-A. Aquat. Microb. Ecol. 77, 128-138. doi: 10.3354/ ame01794

Fernandez, C., Farías, L., and Ulloa, O. (2011). Nitrogen fixation in denitrified marine waters. PLoS ONE 6:e20539. doi: 10.1371/journal.pone.0020539

Fish, J. A., Chai, B., Wang, Q., Sun, Y., Brown, C. T., Tiedje, J. M., et al. (2013). FunGene: the functional gene pipeline and repository. Front. Microbiol. 4:291. doi: $10.3389 /$ fmicb.2013.00291

Furnas, M. (2003). Catchments and Corals: Terrestrial Runoff to the Great Barrier Reef. Townsville: Australian Institute of Marine Science.

Furnas, M., Alongi, D., McKinnon, D., Trott, L., and Skuza, M. (2011). Regionalscale nitrogen and phosphorus budgets for the northern $\left(14{ }^{\circ} \mathrm{S}\right)$ and central $\left(17^{\circ} \mathrm{S}\right)$ Great Barrier Reef shelf ecosystem. Cont. Shelf Res. 31, 1967-1990. doi: 10.1016/j.csr.2011.09.007

Furnas, M., Mitchell, A., Skuza, M., and Brodie, J. (2005). In the other 90\%: phytoplankton responses to enhanced nutrient availability in the great barrier reef lagoon. Mar. Pollut. Bull. 51, 253-265. doi: 10.1016/j.marpolbul.2004. 11.010

Furnas, M., Mitchell, A. W., and Skuza, M. (1995). Nitrogen and Phosphorus Budgets for the Central Great Barrier Reef Shelf. Townsville: Great Barrier Reef Marine Park Authority.

Furnas, M. J., and Mitchell, A. W. (1996). Nutrient imputs into the central Great Barrier Reef (Australia) from subsurface intrusions of Coral Sea waters: a two-dimentional displacement model. Cont. Shelf Res. 16, 1127-1148.

Garcia, N., Raimbault, P., and Sandroni, V. (2007). Seasonal nitrogen fixation and primary production in the Southwest Pacific: nanoplankton diazotrophy and transfer of nitrogen to picoplankton organisms. Mar. Ecol. Prog. Ser. 343, 25-33. doi: $10.3354 /$ meps 06882

Gasol, J. M., and del Giorgio, P. A. (2000). Using flow cytometry for counting natural planktonic bacteria and understanding the structure of planktonic bacterial communities. Sci. Mar. 64, 197-224. doi: 10.3989/scimar.2000. 64 n 2197

Glibert, P. M., and Bronk, D. A. (1994). Release of dissolved organic nitrogen by marine diazotrophic cyanobacteria, Trichodesmium spp. Appl. Environ. Microbiol. 60, 3996-4000.

Großkopf, T., Mohr, W., Baustian, T., Schunck, H., Gill, D., Kuypers, M. M. M., et al. (2012). Doubling of marine dinitrogen-fixation rates based on direct measurements. Nature 488, 361-364. doi: 10.1038/nature11338

Hearn, C., Atkinson, M., and Falter, J. (2001). A physical derivation of nutrientuptake rates in coral reefs: effects of roughness and waves. Coral Reefs 20 , 347-356. doi: 10.1007/s00338-001-0185-6

Heller, P., Tripp, H. J., Turk-Kubo, K., and Zehr, J. P. (2014). ARBitrator: a software pipeline for on-demand retrieval of auto-curated nifH sequences from GenBank. Bioinformatics 30, 1-8. doi: 10.1093/bioinformatics/btu417
Hewson, I., Moisander, P. H., Morrison, A. E., and Zehr, J. P. (2007). Diazotrophic bacterioplankton in a coral reef lagoon: phylogeny, diel nitrogenase expression and response to phosphate enrichment. ISME J. 1, 78-91. doi: 10.1038/ismej. 2007.5

Holmes, R. M., Aminot, A., Kerouel, R., Hooker, B. A., and Peterson, B. J. (1999). A simple and precise method for measuring ammonium in marine and freshwater ecosystems. Can. J. Fish. Aquat. Sci. 56, 1801-1808. doi: 10.1139/ cjfas- 56-10-1801

Karl, D., Michaels, A., Bergman, B., Capone, D., Carpenter, E., Letelier, R., et al. (2002). Dinitrogen fixation in the world's oceans. Biogeochemistry 5, 47-98. doi: 10.1023/A:1015798105851

Klawonn, I., Lavik, G., Böning, P., Marchant, H. K., Dekaezemacker, J., Mohr, W., et al. (2015). Simple approach for the preparation of 15N2-enriched water for nitrogen fixation assessments: evaluation, application and recommendations. Front. Microbiol. 6:769. doi: 10.3389/fmicb.2015.00769

Knapp, A., Dekaezemacker, J., Bonnet, S., Sohm, J., and Capone, D. (2012). Sensitivity of Trichodesmium erythraeum and Crocosphaera watsonii abundance and $\mathrm{N} 2$ fixation rates to varying $\mathrm{NO}_{3}^{-}$and $\mathrm{PO}_{4}^{3-}$ concentrations in batch cultures. Aquat. Microb. Ecol. 66, 223-236. doi: 10.3354/ame01577

Knapp, A. N. (2012). The sensitivity of marine N2 fixation to dissolved inorganic nitrogen. Front. Microbiol. 3:374. doi: 10.3389/fmicb.2012.00374

Kumar, S., Stecher, G., and Tamura, K. (2016). MEGA7: molecular evolutionary genetics analysis version 7.0 for bigger datasets. Mol. Biol. Evol. 33:msw054. doi: 10.1093/molbev/msw054

Kustka, A. B., Sañudo-Wilhelmy, S. A., Carpenter, E. J., Capone, D., Burns, J., and Sunda, W. G. (2003). Iron requirements for dinitrogen- and ammoniumsupported growth in cultures of Trichodesmium (IMS 101): comparison with nitrogen fixation rates and iron:carbon ratios of field populations. Limnol. Oceanogr. 48, 1869-1884. doi: 10.4319/lo.2003.48.5.1869

Langlois, R., Großkopf, T., Mills, M., Takeda, S., and LaRoche, J. (2015). Widespread distribution and expression of Gamma A (UMB), an uncultured, diazotrophic, $\gamma$-Proteobacterial nifH Phylotype. PLOS ONE 10:e0128912. doi: 10.1371/journal.pone.0128912

Larkum, A. W. D., Kennedy, I. R., and Muller, W. J. (1988). Nitrogen fixation on a coral reef. Mar. Biol. 98, 143-155. doi: 10.2216/10031-8884-14-2-87.1

Lee Chen, Y., Tuo, S., and Chen, H. (2011). Co-occurrence and transfer of fixed nitrogen from Trichodesmium spp. to diatoms in the low-latitude Kuroshio Current in the NW Pacific. Mar. Ecol. Prog. Ser. 421, 25-38. doi: 10.3354/ meps08908

Lema, K. A., Willis, B. L., and Bourne, D. G. (2012). Corals form characteristic associations with symbiotic nitrogen-fixing bacteria. Appl. Environ. Microbiol. 78, 3136-3144. doi: 10.1128/AEM.07800-11

Lema, K. A., Willis, B. L., and Bourne, D. G. (2014). Amplicon pyrosequencing reveals spatial and temporal consistency in diazotroph assemblages of the Acropora millepora microbiome. Environ. Microbiol. 16, 3345-3359. doi: 10.1111/1462-2920.12366

Lesser, M. P., Falcón, L. I., Rodríguez-Román, A., Enríquez, S., HoeghGuldberg, O., and Iglesias-Prieto, R. (2007). Nitrogen fixation by symbiotic cyanobacteria provides a source of nitrogen for the scleractinian coral Montastraea cavernosa. Mar. Ecol. Prog. Ser. 346, 143-152. doi: 10.3354/ meps07008

Lesser, M. P., Mazel, C. H., Gorbunov, M. Y., and Falkowski, P. G. (2004). Discovery of symbiotic nitrogen-fixing cyanobacteria in corals. Science 305, 997-1000.

Loscher, C. R., Bourbonnais, A., Dekaezemacker, J., Charoenpong, C. N., Altabet, M. A., Bange, H. W., et al. (2016). N2 fixation in eddies of the eastern tropical South Pacific Ocean. Biogeosciences 13, 2889-2899. doi: 10.5194/bg-13-28892016

Luo, Y. W., Doney, S. C., Anderson, L. A., Benavides, M., Berman-Frank, I., Bode, A., et al. (2012). Database of diazotrophs in global ocean: abundance, biomass and nitrogen fixation rates. Earth Syst. Sci. Data 4, 47-73. doi: 10.5194/ essd-4-47-2012

Marie, D., Partensky, F., Jacquet, S., and Vaulot, D. (1997). Enumeration and cell cycle analysis of natural populations of marine picoplankton by flow cytometry using the nucleic acid stain SYBR Green I. Appl. Environ. Microbiol. 63, 186-193. doi: 10.1111/j.1365-294X.2009.04480.x

Masuda, T., Furuya, K., Kodama, T., Takeda, S., and Harrison, P. J. (2013). Ammonium uptake and dinitrogen fixation by the unicellular 
nanocyanobacterium Crocosphaera watsonii in nitrogen-limited continuous cultures. Limnol. Oceanogr. 58, 2029-2036. doi: 10.4319/lo.2013.58.6.2029

McKinna, L., Furnas, M., and Ridd, P. (2011). A simple, binary classification algorithm for the detection of Trichodesmium spp. within the Great Barrier Reef using MODIS imagery. Limnol. Oceanogr. Methods 9, 50-66. doi: 10.4319/lom. 2011.9.50

Messer, L. F., Doubell, M., Jeffries, T. C., Brown, M. V., and Seymour, J. R. (2015a). Prokaryotic and diazotrophic population dynamics within a large oligotrophic inverse estuary. Aquat. Microb. Ecol. 74, 1-15. doi: 10.3354/ame01726

Messer, L. F., Mahaffey, C., Robinson, C. M., Jeffries, T. C., Baker, K. G., Isaksson, J. B., et al. (2015b). High levels of heterogeneity in diazotroph diversity and activity within a putative hotspot for marine nitrogen fixation. ISME J. 10, 1499-1513. doi: 10.1038/ismej.2015.205

Meyer, J., Loscher, C. R., Neulinger, S. C., Reichel, A. F., Loginova, A., Borchard, C., et al. (2016). Changing nutrient stoichiometry affects phytoplankton production, DOP accumulation and dinitrogen fixation - a mesocosm experiment in the eastern tropical North Atlantic. Biogeosciences 13, 781-794. doi: 10.5194/bg-13-781-2016

Mohr, W., Großkopf, T., Wallace, D. W. R., and LaRoche, J. (2010). Methodological underestimation of oceanic nitrogen fixation rates. PLoS ONE 5:e12583. doi: 10.1371/journal.pone.0012583

Moisander, P. H., Beinart, R. A., Hewson, I., White, A. E., Johnson, K. S., Carlson, C. A., et al. (2010). Unicellular cyanobacterial distributions broaden the oceanic N2 fixation domain. Science 327, 1512-1514. doi: 10.1126/science.1185468

Moisander, P. H., Beinart, R. A., Voss, M., and Zehr, J. P. (2008). Diversity and abundance of diazotrophic microorganisms in the South China Sea during intermonsoon. ISME J. 2, 954-967. doi: 10.1038/ismej.2008.84

Moisander, P. H., Serros, T., Paerl, R. W., Beinart, R. A., and Zehr, J. P. (2014). Gammaproteobacterial diazotrophs and nifH gene expression in surface waters of the South Pacific Ocean. ISME J. 8, 1962-1973. doi: 10.1038/ismej.2014.49

Montoya, J. P., Voss, M., Kahler, P., and Capone, D. G. (1996). A simple, highprecision, high-sensitivity tracer assay for N2 fixation. Appl. Environ. Microbiol. 62, 986-993.

Mulholland, M. R., and Bernhardt, P. W. (2005). The effect of growth rate, phosphorus concentration, and temperature on N2 fixation, carbon fixation, and nitrogen release in continuous cultures of Trichodesmium IMS101. Limnol. Oceanogr. 50, 839-849. doi: 10.4319/lo.2005.50.3.0839

Mulholland, M. R., Bernhardt, P. W., Heil, C. A., Bronk, D. A., and Neil, J. M. O. (2006). Nitrogen fixation and release of fixed nitrogen by Trichodesmium spp. in the Gulf of Mexico. Limnol. Oceanogr. 51, 1762-1776. doi: 10.4319/lo.2006. 51.4.1762

Mulholland, M. R., Mulholland, M. R., Bronk, D. A., Bronk, D. A., Capone, D. G., and Capone, D. G. (2004). Dinitrogen fixation and release of ammonium and dissolved organic nitrogen by Trichodesmium IMS101. Aquat. Microb. Ecol. 37, 85-94.

Olson, N. D., and Lesser, M. P. (2013). Diazotrophic diversity in the Caribbean coral, Montastraea cavernosa. Arch. Microbiol. 195, 853-859. doi: 10.1007/ s00203-013-0937-z

Polyviou, D., Hitchcock, A., Baylay, A. J., Moore, C. M., and Bibby, T. S. (2015). Phosphite utilisation by the globally important marine diazotroph Trichodesmium. Environ. Microbiol. Rep. 7, 824-830. doi: 10.1111/1758-2229. 12308

Santos, H. F., Carmo, F. L., Duarte, G., Dini-Andreote, F., Castro, C. B., Rosado, A. S., et al. (2014). Climate change affects key nitrogen-fixing bacterial populations on coral reefs. ISME J. 8, 2272-2279. doi: 10.1038/ismej.2014.70

Schaffelke, B., Carleton, J., Skuza, M., Zagorskis, I., and Furnas, M. J. (2012). Water quality in the inshore great barrier reef lagoon: implications for long-term monitoring and management. Mar. Pollut. Bull. 65, 249-260. doi: 10.1016/j. marpolbul.2011.10.031

Seymour, J. R., Seuront, L., and Mitchell, J. G. (2007). Microscale gradients of planktonic microbial communities above the sediment surface in a mangrove estuary. Estuar. Coast. Shelf Sci. 73, 651-666. doi: 10.1016/j.ecss.2007.03.004
Somes, C. J., and Oschlies, A. (2015). On the influence of "non-Redfield" dissolved organic nutrient dynamics on the spatial distribution of $\mathrm{N}_{2}$ fixation and the size of the marine fixed nitrogen inventory. Global Biogeochem. Cycles 29, 973-993. doi: 10.1002/2014GB005050

Tamura, K., and Nei, M. (1993). Estimation of the number of nucleotide substitutions in the control region of mitochondrial DNA in humans and chimpanzees. Mol. Biol. Evol. 10, 512-526. doi: 10.1093/molbev/ msl149

Turk-Kubo, K. A., Achilles, K. M., Serros, T. R. C., Ochiai, M., Montoya, J. P., and Zehr, J. P. (2012). Nitrogenase (nifH) gene expression in diazotrophic cyanobacteria in the Tropical North Atlantic in response to nutrient amendments. Front. Microbiol. 3:368. doi: 10.3389/fmicb.2012.00386

Turk-Kubo, K. A., Frank, I. E., Hogan, M. E., Desnues, A., Bonnet, S., and Zehr, J. P. (2015). Diazotroph community succession during the VAHINE mesocosm experiment (New Caledonia lagoon). Biogeosciences 12, 7435-7452. doi: 10.5194/bg-12-7435-2015

Waterhouse, J., Brodie, J., Lewis, S., and Mitchell, A. (2012). Quantifying the sources of pollutants in the great barrier reef catchments and the relative risk to reef ecosystems. Mar. Pollut. Bull. 65, 394-406. doi: 10.1016/j.marpolbul.2011. 09.031

Webb, K. L., Dupaul, W. D., Wiebe, W., Sottile, W., and Johannes, R. E. (1975). Enewetak(Eniwetok) atoll: aspects of the nitrogen cycle on a coral reef. Limnol. Oceanogr. 20, 198-210. doi: 10.4319/lo.1975.20.2.0198

Wiebe, W. J., Johannes, R. E., and Webb, K. L. (1975). Nitrogen fixation in a coral reef community. Science 188, 257-259. doi: 10.1126/science.188. 4185.257

Wilson, S. T., Bottjer, D., Church, M. J., and Karl, D. M. (2012). comparative assessment of nitrogen fixation methodologies, conducted in the oligotrophic north pacific ocean. Appl. Environ. Microbiol. 78, 6516-6523. doi: 10.1128/ AEM.01146-12

Woebken, D., Burow, L. C., Behnam, F., Mayali, X., Schintlmeister, A., Fleming, E. D., et al. (2014). Revisiting N2 fixation in guerrero negro intertidal microbial mats with a functional single-cell approach. ISME J. 9144, 1-12. doi: 10.1038/ ismej.2014.144

Zehr, J. P., Jenkins, B. D., Short, S. M., and Steward, G. F. (2003). Nitrogenase gene diversity and microbial community structure: a cross-system comparison. Environ. Microbiol. 5, 539-554.

Zehr, J. P., and McReynolds, L. A. (1989). Use of degenerate oligonucleotides for amplification of the nifH gene from the marine cyanobacterium Trichodesmium thiebautii. Appl. Environ. Microbiol. 55, 2522-2526.

Zehr, J. P., Shilova, I. N., Farnelid, H. M., del Carmen Muñoz-Marín, M., and Turk-Kubo, K. A. (2016). Unusual marine unicellular symbiosis with the nitrogen-fixing cyanobacterium UCYN-A. Nat. Microbiol. 2:16214. doi: 10. 1038/nmicrobiol.2016.214

Zehr, J. P., and Turner, P. J. (2001). Nitrogen fixation: nitrogenase genes and gene expression. Methods Microbiol. 30, 271-285.

Zhang, Y., Yang, Q., Ling, J., Van Nostrand, J. D., Shi, Z., Zhou, J., et al. (2016). The shifts of diazotrophic communities in spring and summer associated with coral Galaxea astreata, Pavona decussata, and Porites lutea. Front. Microbiol. 7:1870. doi: $10.3389 /$ fmicb. 2016.01870

Conflict of Interest Statement: The authors declare that the research was conducted in the absence of any commercial or financial relationships that could be construed as a potential conflict of interest.

Copyright (C) 2017 Messer, Brown, Furnas, Carney, McKinnon and Seymour. This is an open-access article distributed under the terms of the Creative Commons Attribution License (CC BY). The use, distribution or reproduction in other forums is permitted, provided the original author(s) or licensor are credited and that the original publication in this journal is cited, in accordance with accepted academic practice. No use, distribution or reproduction is permitted which does not comply with these terms. 